The Northern Review

yukoncollege.yk.ca/review

\title{
Report
}

\section{île-à-la-Crosse Northern Village, Saskatchewan: A New Approach to Understanding Northern Communities} Greg Finnegan and Ken Coates

Abstract: The Arctic Council Sustainable Development Working Group (SDWG) has been developing socio-economic indicators (SEI) for the Arctic for over a decade, with an emphasis on finding and applying indicators that speak to the people and cultures of the Arctic. The SDWG's work is encapsulated in three studies: the Arctic Human Development Report 2004 (AHDR), the Arctic Social Indicators (ASI) 2010, and case studies that were captured in Arctic Social Indicators 2013. In this study, we apply the ASI 2010 indicators to the northern Saskatchewan Métis community of Île-à-la-Crosse, using the available Canadian and Saskatchewan socio-economic indicators, in order to test the applicability of the ASI 2010 methodology to a northern provincial community. In this exercise, we were hampered by the failure of the National Household Survey of 2011 and the dearth of published provincial socio-economic indicators. For instance, the 2013 case studies indicate that territorial governments in the Far North provide a greater wealth of applicable ASI 2010 data for remote Indigenous communities than does the province of Saskatchewan. Finally, the federal government of Canada continues to demand fees for services in order to access data from sources as essential as the Aboriginal People's Survey (APS) 2012 limiting access to data that is critical for the analysis of resiliency and inequality in Indigenous communities. Overall, we found that the Arctic social indicators provided a clear and concise picture of the social inequalities that exist between northern and southern Saskatchewan, while also demonstrating the strength and resiliency of this Métis community.

\section{Introduction}

Northern communities face enormous pressures to adapt to changing political, economic, climatic, and social circumstances. They do so with profound disadvantages that range from limited local professional capacity to small populations and economic marginalization. Most often, they also 
suffer from the basic information needed to make informed decisions. The smallest communities in the country, particularly Aboriginal settlements, have little information at their disposal to plan properly for the future. Working with communities in northern Saskatchewan, the International Centre for Northern Governance and Development (ICNGD) at the University of Saskatchewan has been developing a community-based approach of empowerment through data collection and analysis.

This process has two phases, the first of which is represented here. As a starting point, ICNGD is assembling a statistical profile of each Aboriginal community in Northern Saskatchewan. This profile-similar to the evidentiary base that federal and provincial governments use for making decisions about Aboriginal communities-is designed to be shared with the communities. As a second phase, the centre will work with the communities to evaluate the profile and identify gaps in understanding. The communities will help in identifying appropriate data collection procedures and will produce a revised profile based on a combination of public statistics and community-generated data. The ICNGD approach is based on a commitment to "data sovereignty," in which Indigenous communities are supported in their efforts to collect and maintain data for their communities.

The Île-à-la-Crosse report published here reflects the profile that has emerged using data that is publicly available. The report has been shared with community leaders in Île-à-la-Crosse; their preliminary critique will form the basis for a revised data collection and analysis process.

Arctic Social Indicators 2010

The Arctic Council's Sustainable Development Working Group (SDWG) has been developing socio-economic indicators (SEI) for over a decade. Three studies have influenced the development of the Arctic social indicators used in this report: The Arctic Human Development Report 2004 (AHDR), Arctic Social Indicators 2010 (ASI), and Arctic Social Indicators 2013-Case Studies. ${ }^{1}$ ASI stresses social indicators that focus more on the people of the North and their empowerment, than on Western market concepts of well-being dominated by wealth generation. Yet, the ASI approach also incorporates a range of the standard economic and labour indicators associated with economic progress. These indicators monitor trends in human development, encourage evidence-based policymaking, and create baselines that make it possible for researchers and governments to track the impacts and benefits of development projects or government investments, and to build awareness of existing conditions. In 
this way, community leaders can develop targets to improve community conditions or preserve cultural integrity.

The pragmatic approach of the ASI is to choose a small, representative set of indicators, or key domains, that communities can track over time. ${ }^{2}$ Such indicators condense real-life complexity into a manageable level of meaningful information. ${ }^{3}$ In some cases, it is necessary to use proxy measures (or statistics that are believed to approximate the actual statistical information desired) to infer trends in social systems, communities, or regions. ${ }^{4}$ The ASI found that:

- Many Arctic communities do not rank high in terms of life expectancy, particularly among Indigenous peoples where suicide rates and accidental-death rates are high;

- Most Arctic residents today are literate, but school enrolments, especially at the secondary and tertiary levels, are comparatively low;

- GDP per capita is often deceptive as a measure of well-being in the Arctic since much of the income associated with extractive industries flows out of the Arctic (leakage) and into the income streams of extraterritorial corporations; and

- GDP per capita at the community level is comparatively low in many parts of the Arctic, and it does not take into account transfer payments and the informal economy.

The ASI discovered that, despite the relatively low score on measures such as the United Nations Human Development Index (UNHDI), many individuals in the Circumpolar North exhibit a strong sense of well-being (Young 2010). To better understand this sense of well-being, the Arctic Human Development Report process identified three additional domains: fate control, cultural well-being and vitality, and contact with nature (AHDR 2004; ASI 2010). Following the ASI 2010 approach, this study measures human development in the northern Saskatchewan community of Île-à-la-Crosse using a distinct series of indicators organized under six domains:

- Material well-being

- Health \& population

- Education

- Cultural integrity - belonging to a viable local culture

- Fate control-guiding one's destiny

- Contact with nature-interacting closely with the natural world 
Aboriginal communities in the Northern Saskatchewan region have to cope with the costs and consequences of remoteness. These small settlements often lack connectivity to major urban centres, remain resource dependent, lack access to public goods and services, have lower incomes and weak educational outcomes, and often suffer from poorer housing quality and expensive foodstuffs. Applying the ASI indicators to these communities serves as a means of setting socio-economic community baselines for future assessment of the impacts of policy changes or economic inputs.

This case study is a goodness-of-fit exercise for the ASI social indicators for Île-à-la-Crosse, Saskatchewan. It represents a first-of-its-kind testing of these concepts against the extant statistical base and publicly available data in Canada's provincial North The ASI approach investigates the dualistic nature of the North's economy in which two separate economies coexist-one that is market-driven, with valued outputs, high capitalization costs, and economic rents (the extraction of natural resources), and the other, traditional economy, that is based on hunting and gathering, traditional lifestyles, and interconnectedness with the land. The ability to test an example from northern Saskatchewan into the ASI indicators allows a form of gap analysis between what is expected against what is observed. In this case, the expected elements are the ASI indicators; the observed information is the publicly available Canadian data. As some key ASI community markers are not accessible from government, we will use this study to direct future community-based research on these missing ASI indicators.

\section{Data Sources}

This study is informed by the Census of Canada, 1996 through 2011, but unfortunately not by the ill-fated National Household Survey 2011 (NHS) as the overall non-response rate for the NHS was too high in Île-à-la-Crosse for its release. ${ }^{5}$ Health care data can be accessed through Saskatchewan Regional Health Authority reports. Unfortunately, many social well-being outcomes can only be explored at an aggregated regional scale through the Canadian Community Health Survey (CCHS) or the Aboriginal Peoples Survey (APS). ${ }^{6}$ We should also note that census data for small communities can often be problematic. As Petrov (2013) cautions: 
In very small communities it is extremely difficult to obtain a complete dataset or to ensure its accuracy. Statistics Canada rounds its census data to the nearest 0 or 5 , generating a rounding error that may be very significant to smaller populations. For this reason a substantial number of variables are suppressed and all available ones must be used with caution. In addition, the "small numbers problem" creates datasets with high variances and generally erratic behavior; both of which are conditions that can invalidate statistical analysis.

\section{Demographic Overview}

Northern Saskatchewan is home to about 39,600 people, or $3.5 \%$ of the provincial population. ${ }^{7}$ Population densities are low. The northern population is predominately of Aboriginal heritage, with people living in thirty-five small municipalities and thirty-five First Nation reserve communities. Île-à-la-Crosse is a predominately Aboriginal community of 1,365 (2011 Census), with $92.5 \%$ of the population self-declaring as Aboriginal in the 2006 Census, slightly down from about $96 \%$ in 2001 (Table 1). Due to the failure of the National Household Survey (NHS) and the unwillingness of the then Canadian federal government to include the Aboriginal population questions in the 2011 Census, we have no official breakout of the Aboriginal community since 1996. In that year, the percentage of the community that declared as Métis was $86 \%$ with $8 \%$ First

Nation and 6\% non-Aboriginal. Based on 2011 Census language data, we can determine that the First Nation community is primarily composed of members of the Cree Nation, with some 200 Cree mother-tongue speakers, many of whom are probably declaring as Métis. The failure of the NHS 2011 is a recurring theme throughout this study and is illustrative of the data collection and complications created by the replacement of the mandatory long-form census with the voluntary National Household Survey in 2011. In 2016, the long-form census has been reinstated, but the impact of the NHS 2011 decision created a permanent gap in our national databases. ${ }^{9}$ 
Table 1. Île-à-la-Cross population characteristics, 2006 \& 2011

\begin{tabular}{|c|c|c|c|}
\hline Population Characteristics & 2011 & 2006 & 2001 \\
\hline Population & 1365 & 1341 & 1268 \\
\hline$\%$ change in pop. from previous census & $1.8 \%$ & $5.8 \%$ & $-9.6 \%$ \\
\hline Median age & 27.4 & 24.7 & 22 \\
\hline Total number of private dwellings & 443 & 485 & 421 \\
\hline$\%$ change in dwellings from previous census & $-9.5 \%$ & $15.2 \%$ & $7.9 \%$ \\
\hline Aboriginal population & Suppressed & 1240 & 1215 \\
\hline Aboriginal population as a $\%$ of total & Suppressed & $92.5 \%$ & $96.4 \%$ \\
\hline Land area $\left(\mathrm{km}^{2}\right) 2011$ Census & 23.84 & 23.84 & 23.84 \\
\hline
\end{tabular}

The Northern Village of Île-à-la-Crosse is situated in the Canadian Shield, with its ice-sheet-scoured landscape of forests, rivers, and lakes. It is $380 \mathrm{~km}$ northwest of Prince Albert (Saskatchewan's third largest city and the north's major urban economy) and $63 \mathrm{~km}$ north of Buffalo Narrows (population 1,400, and the closest regional service centre).

The Canadian North attracts considerable interest from resource firms, and mining is, without a doubt, the largest economic driver in Northern Saskatchewan. The Saskatchewan Mining Association estimates that some 2,135 employees work in mining, plus another 1,050 contract employees (Table 2).$^{10}$ Exports of Saskatchewan uranium alone totalled over $\$ 1$ billion in 2011.11 As the Saskatchewan Economic Review noted: "Saskatchewan continues to be a major player in the global uranium market, and uranium mining continues to be a significant component of the provincial economy" $(2013,3)$. While Île-à-la-Crosse is remote from the working mines, it is part of the northern labour market on which mining firms draw. It is also close, by air, to the Athabasca oil sands complex near Fort McMurray. 
Table 2. The Northern Saskatchewan mining region

\begin{tabular}{|c|c|c|c|c|}
\hline Mine & Resource & $\begin{array}{c}\text { Estimated } \\
\text { Employment }\end{array}$ & Operational Dates & Status \\
\hline Cluff Lake & Uranium & & 1980-2002 & Decommissioned* \\
\hline Key Lake & Uranium & $\begin{array}{c}900 \text { employees } \\
\text { and }\end{array}$ & 1983-present & \\
\hline $\begin{array}{l}\text { McArthur } \\
\text { River }\end{array}$ & Uranium & $\begin{array}{l}750 \text { contractors } \\
\text { combined }\end{array}$ & 1997-present & \\
\hline Cigar Lake & Uranium & $\begin{array}{l}600 \text { at full } \\
\text { production }\end{array}$ & 2014-opening & \\
\hline McLean Lake & Uranium & & 1999-present & \\
\hline Rabbit & Uranium & $\begin{array}{c}300 \text { Staff } \\
300 \text { Contractors }\end{array}$ & 1975-present & \\
\hline SeeBee Mine & Gold & 335 employees & 1991-present & \\
\hline $\begin{array}{l}\text { Laurel Lake } \\
\text { Mine }\end{array}$ & Gold & & & \\
\hline Midwest Mine & Uranium & & Proposed & \\
\hline $\begin{array}{l}\text { Millennium } \\
\text { Mine }\end{array}$ & Uranium & $\begin{array}{c}\text { In Regulatory } \\
\text { Review }\end{array}$ & Proposed & \\
\hline
\end{tabular}

Sources see: http://www.saskmining.ca/map/Map/map.html\#top

* Decommissioned mines commonly have caretaker and remediation staff.

In order to better understand how the resource developments benefit and/or impact First Nations communities in the region, it is necessary to have a "baseline" measurement of the socio-economic condition of these communities prior to new developments, which the ASI approach provides. However, the community is not a greenfield site-it has suffered from cumulative development impacts over hundreds of years, surely beginning with the fur trade, and we need to recognize the long history of development and conflict over resource exploitation that has occurred here. 


\section{Population Dynamics}

The 2011 Census reported that the Île-à-la-Crosse population had increased by only $2 \%$ since 2006 , making the community one of the slower growing populations in the North. The median age of the population was 27.4 years of age. This is much lower than the median age for Saskatchewan at 38.2 years of age or for Canada at 40.6. For northern Canada, however, this is one of the higher median ages, as median ages in many northern communities are around 20 years of age. Between 1986 and 2011, the population of the community grew by $33 \%$ (or by $1.3 \%$ annually), although the population appears to have peaked in 1996 at 1,403 prior to dropping below 1,300 in 2001 and slowly increasing again through 2006 and 2011 (Figure 1). This is a similar growth rate to the northern Saskatchewan Métis community of Pinehouse, but higher than the negative growth rate recorded in the Métis community of Buffalo Narrows over this period. In contrast, La Loche, another northern Saskatchewan Métis community, had a $61 \%$ growth rate, showing steady growth through all six census cycles.

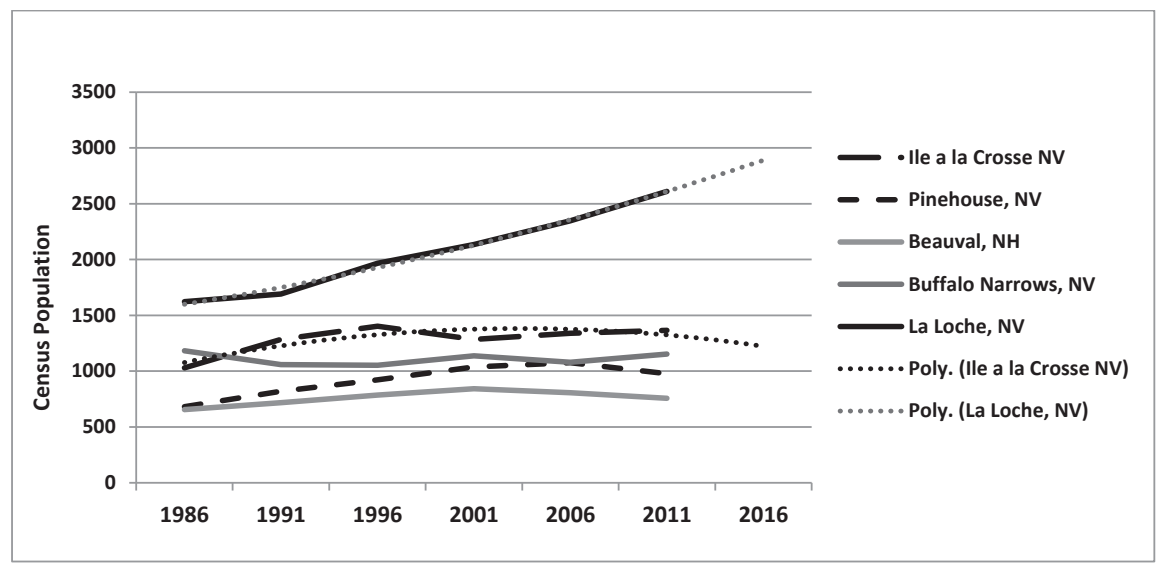

Figure 1. Northern Saskastchewan, selected population trends 1986 to 2016

Population indicators are best interpreted in the form of time series datasets broken down by age, sex, and ethnicity. Secondary indicators derived from population numbers include birth rates, teenage birth rates, life expectancy, infant or child mortality rates, population change and projections, and ethnic composition of the population. ${ }^{12}$ Each of these indicators can have relevance for capacity building and socio-economic development. Between 1986 and 2011, the community's population shows a pattern of growth and decline, which is not unusual in a resource community. Figure 2 places Île-à-la-Crosse on a continuum between the 
largest census-reporting northern community, La Ronge $(2,743)$, and the smallest, Dore Lake (28). ${ }^{13}$ The Saskatchewan Bureau of Statistics confirms that in smaller communities there is more transiency with people moving from reserves to towns and villages, and back. ${ }^{14}$

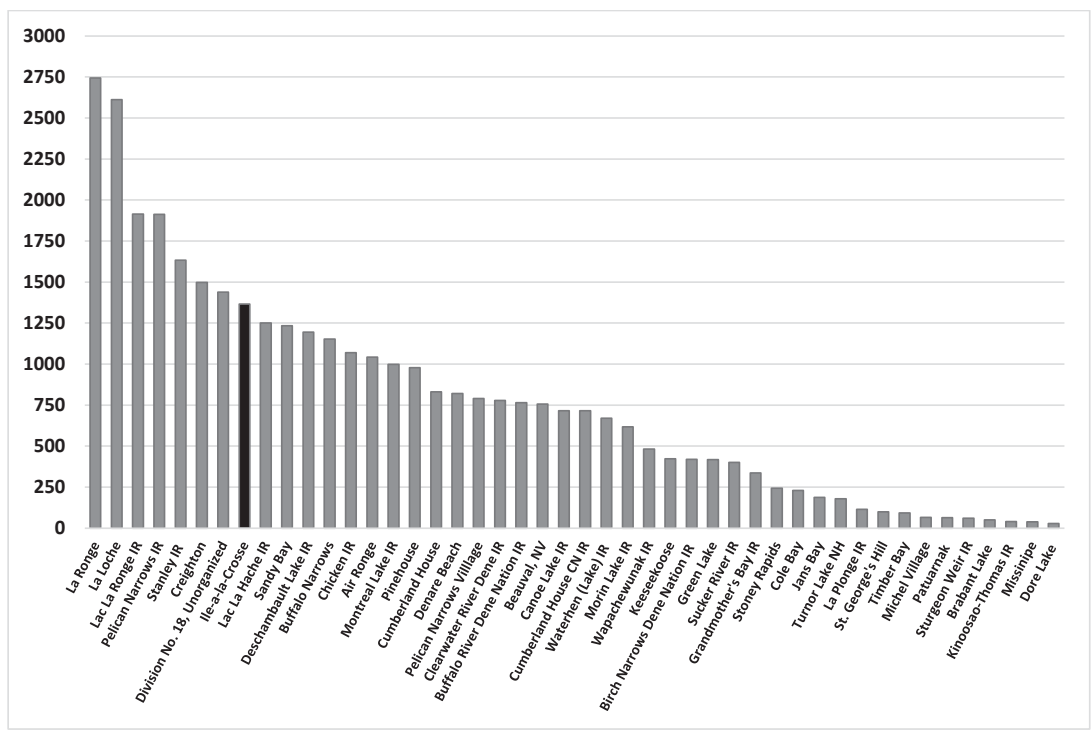

Figure 2. Northern Saskatchewan, populated census places 2011, with Census Count Amendments, 2014

Male-Female Balance

Population pyramids are a standard means for illustrating age cohort ratios for male and female populations (Figure 3). In 2011, the male/female split in Île-à-la-Crosse was 51\% male to $49 \%$ females. The graph lacks the usual pyramid shape of evenly dispersed age cohorts by sex. ${ }^{15}$

Youth under 20 years of age account for $39 \%$ of the population, with 280 males and 260 females. This slight imbalance generally occurs, with more male children being born than female, although female survival rates are generally higher than males through to adulthood. In comparison to the Canadian population profile, the Île-à-la-Crosse profile is unevenly distributed, with a larger block of youth at its base and a secondary block of adults at between 35 and 59 years of age, suggestive of young adult outmigration. ${ }^{16}$ There are break points on both the female and the male sides of the profile, with a drop in females aged 25-29-just 35 women compared to 50 males; and then, at ages 30-34, men drop off to 25 compared to 40 females. While we can suggest a reason for the female 
difference at 25-29-they are possibly away for educational or career opportunities - the male drop in the 30-34 age cohort is more worrisome, as this is usually the age when men are helping to establish families. If the men were away working, for example as fly-in miners, they would still be deemed residents of the community. Two other plausible scenarios include a higher mortality rate for young males or a higher level of outmigration. The age cohorts balance out for age 35-59, with 205 people of each sex in these cohorts. As usual in northern Aboriginal communities, there are far fewer seniors (65 and over) than in the national distribution.

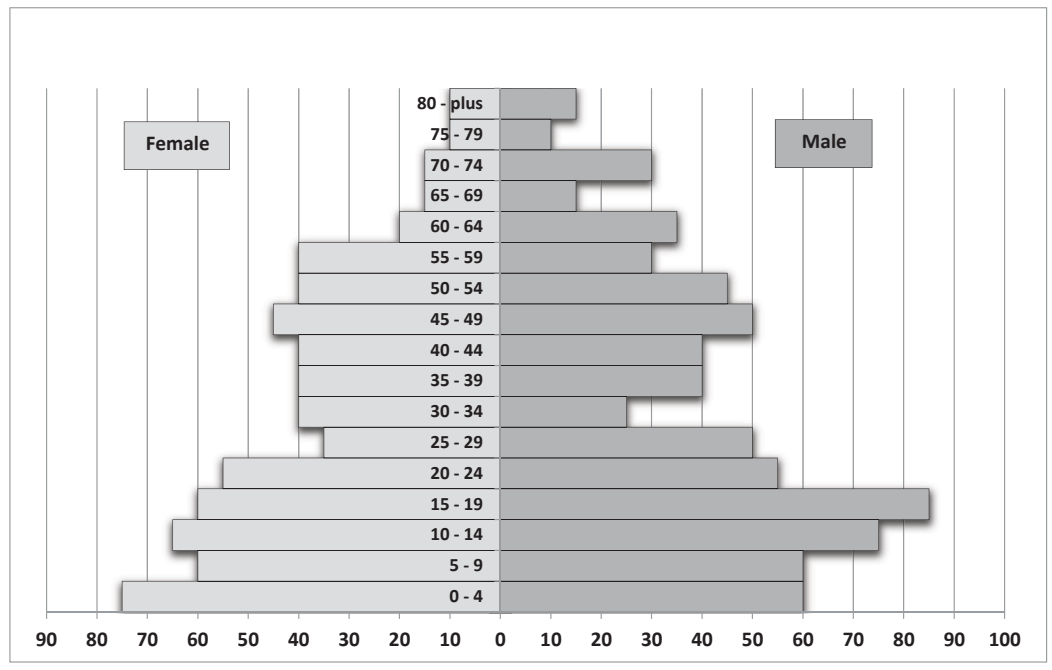

Figure 3. Île-à-la-Cross, Population profile, 2011

\section{Migration and Immigration}

Immigration to remote northern communities is uncommon. This is indeed the case in Île-à-la-Crosse, where $98 \%$ of the 2006 Census population is listed as being at least third generation in Canada. No immigrants to Canada were identified as living in the community. Of the 1,335 people counted in the 2006 Census, only 15 or $1 \%$ were living outside of Saskatchewan one year prior (i.e., in 2005). Although we don't have reliable data for 2011, it is fair to characterize this population as a stable, non-migratory, and probably tight-knit kinship-based community with a high level of interrelatedness. This has positive connotations (stability) for the community. The ASI 2010 suggests that a lack of migrants also has negative consequences-for example, the lack of migrants means that new ideas, cultural discourse, and new social capacity-building and investment may not be occurring. 


\section{Material Well-Being}

The material well-being of a place can be defined as a measure of the control that local residents have over goods and services. The more a local economy can control or manage its inputs and outputs, the better off it will be financially. Obviously, in Île-à-la-Crosse, almost all consumer goods need to be trucked in over long distances, the means of production are primarily controlled by outside agencies and investors, and jobs are scarce. Local control over social well-being is heavily compromised. The Arctic Human Development Report 2004 describes the three main sectors of the Arctic economy as being:

- Formal: Income from market economy transactions;

- Transfer: Income from government transfers (e.g., Territorial Formula Financing in the North, health transfers, transfers to Aboriginal people, pensions, employment insurance, and social assistance);

- Subsistence: Income and value gained from hunting, fishing, trapping, and non-market activities that displace market expenses for store bought goods and add to quality of life.

\section{The Dependent Population}

In order to demonstrate changes in the demographic structure, as well as to estimate the ability to maintain viable economic structures at the household level, Dependency Ratios (DR) can be calculated and mapped over time for each community in the North. Table 3 shows Statistics Canada generated DRs for Canada, Saskatchewan, and the three northern territories. Calculations for Saskatchewan as a whole demonstrate a falling DR -indicating improved standard of living-from $70 \%$ in 2007 to about $66 \%$ in 2011. Île-à-la-Crosse had higher DRs of 91\% in 2011, a considerable improvement from the $120 \%$ recorded in 2001 (Table 4). An improved DR suggests improvements in the costs of household management, in family earnings and savings, in access to healthy food, and in sundry other social and economic issues, as well as in the delivery of public goods and services by government. While a $91 \%$ rate is high by Canadian standards, it is a rather positive outcome in northern Canada where DRs commonly exceeded $100 \%$ in 2011. 
Table 3. Dependency ratio (administrative data) by age group, Canada and the North (ratio) ${ }^{*}$

\begin{tabular}{lrrrrr}
\hline & 2011 & 2010 & 2009 & 2008 & 2007 \\
\hline Canada & 59.1 & 59.1 & 59.3 & 59.5 & 59.5 \\
Yukon & 47.4 & 47.5 & 47.5 & 47.2 & 47.8 \\
Northwest Territories & 53.9 & 54.6 & 55.5 & 55.5 & 56.2 \\
Nunavut & 84.8 & 84.2 & 82.7 & 80.8 & 79.1 \\
Saskatchewan & 66.6 & 67.3 & 68.8 & 69.0 & 70.0 \\
\hline
\end{tabular}

*The ratio of the combined population aged between 0 to 19 years old and the population aged of 65 years and over to the population aged between 20 to 64 years old. This ratio is usually presented as the number of dependents for every 100 people in the working age population. Data are derived from administrative sources on births, deaths, and migration.

Source: Statistics Canada, Demography Division, Table 109-5326, Dependency ratio (2006 Census and administrative data), by age group for July 1st, Canada, provinces, territories, health regions (2011 boundaries) and peer groups, annual (ratio unless otherwise noted). The CANSIM table 109-5326 is an update of CANSIM table 109-5226.

Table 4. Île-à-la-Cross Dependency Ratio 2011

\begin{tabular}{lccc}
\hline Age Range & $\begin{array}{c}\text { Population } \\
\text { 2011 }\end{array}$ & $\begin{array}{c}\text { Population } \\
2006\end{array}$ & $\begin{array}{c}\text { Population } \\
2001\end{array}$ \\
\hline $0-19$ & 530 & 580 & 600 \\
$20-64$ & 710 & 670 & 575 \\
65 and over & 115 & 90 & 90 \\
Total Population for DR & 1,355 & 1,340 & 1,265 \\
DR Ratio & 90.8 & 100 & 120 \\
\hline Source: Calculated by author using Census of Canada data, 2011, 2006 \& \\
2001
\end{tabular}

Single Parent Families and Dependency

Added to the DR dynamic is the high percentage of single parent households in Île-à-la-Crosse, where 150 out of 335 families were headed by a single parent in 2011 (115 Female, 30 Male). This represents 45\% of census families. In contrast, lone parents represented only $16 \%$ of all census families across Canada and in Saskatchewan. Adding to the burden, approximately 90 of these 150 single parent households had two or more children (Table 5). Indeed, 45 of the female-led families actually had three or more children. This increases the responsibility borne by the community, as almost $50 \%$ of all families lack a second income earner 
to care and provide for dependent children-increasing the probability of poorer health, learning, and economic development outcomes. The preponderance of single parent families has increased from 39\% in 2001 to $45 \%$ in 2011 , with the burden primarily upon female parents. Single parent families in the community are a strong indicator of potential familial and socio-economic problems and stresses, demanding further research and greater social support. ${ }^{17}$

Table 5. Île-à-la-Cross, Single-parent families by sex and number of children

\begin{tabular}{|c|c|c|c|c|c|c|}
\hline & \multirow{2}{*}{2011} & \multirow{2}{*}{2006} & \multirow{2}{*}{2001} & 2011 & 2006 & 2001 \\
\hline & & & & as a $\%$ & as a $\%$ & as a $\%$ \\
\hline $\begin{array}{l}\text { Total number of census } \\
\text { families }\end{array}$ & 335 & 325 & 320 & & & \\
\hline $\begin{array}{l}\text { Total lone-parent } \\
\text { families }\end{array}$ & 150 & 120 & 125 & 44.8 & 36.9 & 39.1 \\
\hline Female parent & 115 & 95 & 105 & 76.7 & 79.2 & 84.0 \\
\hline 1 child & 40 & & & 34.8 & & \\
\hline 2 children & 35 & & & 30.4 & & \\
\hline 3 or more children & 45 & & & 39.1 & & \\
\hline Male parent & 30 & 25 & 20 & 20.0 & 20.8 & 16.0 \\
\hline 1 child & 20 & & & 66.7 & & \\
\hline 2 children & 10 & & & 33.3 & & \\
\hline 3 or more children & 0 & & & 0.00 & & \\
\hline
\end{tabular}

Source: Census of Canada, Ile a la Crosse, 2011, 2006, 2001

Note: The published Census data from 2006 and 2001 does not provide a comparable number of children by household category. Due to random rounding, percentages may not add up to $100 \%$.

\section{Crowding}

Crowding is a socio-economic indicator that is calculated using the number of people per household divided by the number of rooms allocated for the use of the people living in the household. Clearly, the quality of one's housing directly affects material well-being as well as health, education, fate control, and cultural well-being. Overcrowding, especially in the North where mould is a major health concern in poorly insulated and badly ventilated housing, is a major health risk. Health-related crowding issues that are recognized by the World Health Organization (WHO) include: 
- Physical: Spread of infectious disease;

- Psychological: Frustration, anxiety;

- Social: Violence;

- High Morbidity and mortality (including suicide).

The number of persons per household, as shown in Table 6, is available from the 2011 Census. The 2006 Census metric for crowding is: "Dwellings with more than one person per room, as a \% of total occupied private dwellings," which was $8 \%$ in Île-à-la-Crosse, or six times higher than Saskatchewan's provincial average of $1 \%$. Nunavut is generally perceived to be the region with the most problematic crowding issues in Canada, with the percentage of large households of five or more persons in the high twenties. For example, $29 \%$ of Rankin Inlet, Nunavut households have five or more persons. Île a la Crosse, at $20 \%$ of households with five or more persons being overcrowded, has a crowding rate that is comparable to a Nunavut community and is more than double the Saskatchewan rate of $9 \%$. Crowding, which is clearly occurring in the community, is a significant indicator of poor social well-being. ${ }^{18}$

Table 6. Île-à-la-Cross and Saskatchewan households by size compared, 2011

\begin{tabular}{rrrrr}
\hline & \multicolumn{2}{c}{ île-à-la-Cross } & \multicolumn{2}{c}{ Saskatchewan } \\
$\begin{array}{r}\text { Total Number of } \\
\text { Households }\end{array}$ & 425 & $\begin{array}{c}\text { As a } \\
\%\end{array}$ & 409,645 & As a \% \\
\hline 1 person & 95 & 22.3 & 114,385 & 27.9 \\
2 persons & 75 & 17.7 & 146,850 & 35.9 \\
3 persons & 85 & 20.0 & 57,410 & 14.0 \\
4 persons & 85 & 20.0 & 53,070 & 13.0 \\
5 persons & 45 & 10.6 & 23,455 & 5.7 \\
6 or more persons & 40 & 9.4 & 14,470 & 3.5 \\
\hline
\end{tabular}

Source: Census of Canada, 2011. Totals may be affected by random rounding

\section{Labour and Employment}

Not surprisingly, Île-à-la-Crosse has experienced considerable difficulty with employment. The census labour force data allow an assessment of Île-à-la-Crosse employment prior to the global recession of 2008, but not afterwards. ${ }^{19}$ While other factors may have come into play between 2006 and 2011, the 2008-2009 recession's impact on mine investment, the drop in mineral exploration investment, and the downturn in demand for 
uranium and oil should have negatively impacted the labour market. The numbers indicate that, between 2001 and 2006, the labour force population for those people aged 15 years and older increased from 575 to 880 (an amazing 53\% growth rate over five years). Meanwhile, the actual labour force (those people working or actively looking for work) increased by $52 \%$, from 300 to 455 . There was also an increase in the number of people employed, which rose from 210 to 395 or by $88 \%$, indicating that these new workers were effectively absorbed into jobs. The number of unemployed actually dropped from 90 to 55 workers (Table 7).

Table 7. Labour force comparative analysis, île-à-la-Crosse 2001 to 2006

\begin{tabular}{|c|c|c|c|c|}
\hline \multirow[b]{2}{*}{ Category } & \multicolumn{3}{|c|}{ Census 2006} & \multirow{2}{*}{$\begin{array}{l}\text { Census } \\
2001^{*} \\
\text { Total }\end{array}$} \\
\hline & Total & Male & Female & \\
\hline $\begin{array}{l}\text { Total population, age } 15 \text { years } \\
\text { and over }\end{array}$ & 880 & 475 & 410 & 575 \\
\hline In the labour force & 455 & 255 & 195 & 300 \\
\hline Employed & 395 & 205 & 195 & 210 \\
\hline Unemployed & 55 & 55 & 0 & 90 \\
\hline Not in the labour force & 425 & 215 & 215 & 280 \\
\hline Participation rate as a $\%$ & 51.7 & 53.7 & 47.6 & 51.6 \\
\hline Employment rate as a \% & 44.9 & 43.2 & 47.6 & 36.3 \\
\hline Unemployment rate as a $\%$ & 12.1 & 21.6 & 0 & 29.6 \\
\hline \multicolumn{5}{|l|}{ * See footnote 18} \\
\hline \multicolumn{5}{|c|}{$\begin{array}{l}\text { Sources: Statistics Canada, 2007, } 2006 \text { Community Profiles, } 2006 \text { Census. Catalogue no. } \\
\text { 92-591-XWE. Ottawa. Released March 13, 2007. http://www12.statcan.ca/census-recen- } \\
\text { sement/2006/dp-pd/prof/92-591/index.cfm?Lang=E; Statistics Canada Île-à-la-Crosse - } \\
\text { Northern Village (Census Subdivision), } 2001 \text { Community Profile. }\end{array}$} \\
\hline
\end{tabular}

Most northern Aboriginal communities have a high percentage of the working age population in the "Not in the Labour Force" (NILF) category, which is the case here with 425 people listed as NILF in 2006, having risen from 280 in 2001. This is effectively $48 \%$ of the 2006 labour force population. This is much higher than the provincial average that fluctuates around $31 \%$. A substantial portion of youth reached maturity between 2001 and 2006, with an additional 305 potential workers-155 actually entered the labour force and the other 145 failed to find work and are captured in the NIFL category. ${ }^{20}$ This means that the community and its regional economy added new jobs and reduced actual unemployment, but still failed to absorb the rapidly maturing population. 


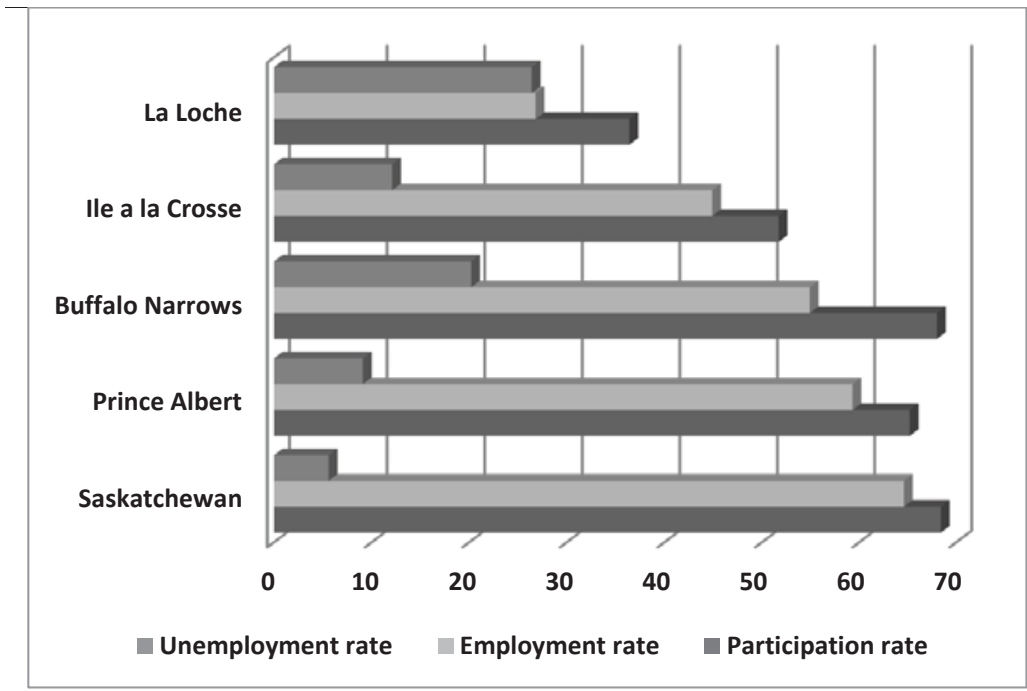

Figure 4. Comparisons of regional employment metrics, Saskatchewan 2006

In many northern communities, a corresponding drop in the unemployment rate, as seen here with the rate dropping from $30 \%$ in 2001 to $12 \%$ in 2006, usually means that workers have given up looking for jobs and moved into the ranks of the NILF category. This is not the case in Île-à-la-Crosse, where we find that the drop from a high rate of unemployment was actually linked to an increase in the employment rate and a high but steady rate of participation. While the employment metrics were very poor in 2001, considerable improvement occurred by 2006, suggesting that the labour market improved prior to the recession of 2008.

When the 2006 labour force data is broken out by sex, it shows considerable differences, with 475 males compared to 410 females in the labour force, and with 255 males compared to 195 females employed. The NILF category had the same number for both, at 215 each. Generally, women outnumber men in the NILF category as women more commonly bear family obligations that take them out of the labour force. This is not the case here. The major unexpected difference between male and female labour market experiences is that 55 males were unemployed compared to no females (0) listed as unemployed.

It is helpful to view Île-à-la-Crosse's employment profile within the larger framework of Saskatchewan (Figure 4). The community does not compare favourably with the dynamic labour market of Saskatchewan or even with Prince Albert, with lower participation and employment rate outcomes and a higher unemployment rate. Île-à-la-Crosse lies on 
a continuum between Saskatchewan as a whole and the city of Prince Albert, which have the higher ratings, and its neighbouring communities of Buffalo Narrows and La Loche, with La Loche having the poorest standings. The major difference in 2006 between Buffalo Narrows and Île-à-la-Crosse was the participation rate, which stood at $68 \%$ for Buffalo Narrows, but only $52 \%$ for Île-à-la-Crosse. However, Île-à-la-Crosse did have a lower unemployment rate at $12 \%$ compared to $20 \%$ for Buffalo Narrows.

\section{Employment Beneficiaries as a Proxy Measure for Employment Activity}

The most current information available for labour market analysis at the community level is the monthly Government of Canada Employment Insurance (EI) beneficiaries data available from Statistics Canada. There are considerable limitations to using this data as beneficiaries have to qualify and then actively seek EI benefits. They must also provide biweekly updates on their status. This means that actual unemployment in a community could be greatly underreported. Figure 5 provides a monthly cycle of EI data for the period May 2014 to May 2015 for all types of EI and both sexes across five sample communities. In this period, Île-à-laCrosse had a maximum of 70 workers and a minimum of 50 workers on regular benefits, with the average for this period being 54 . Creighton, a predominately non-Aboriginal community of 1,500 people (2011 Census), and, in essence, a bedroom community of Flin Flon, Manitoba, had between 10 and 30 workers (average 21) on EI per month-demonstrating the discrepancy in employment between this Métis/Aboriginal community and a predominately non-Aboriginal northern community.

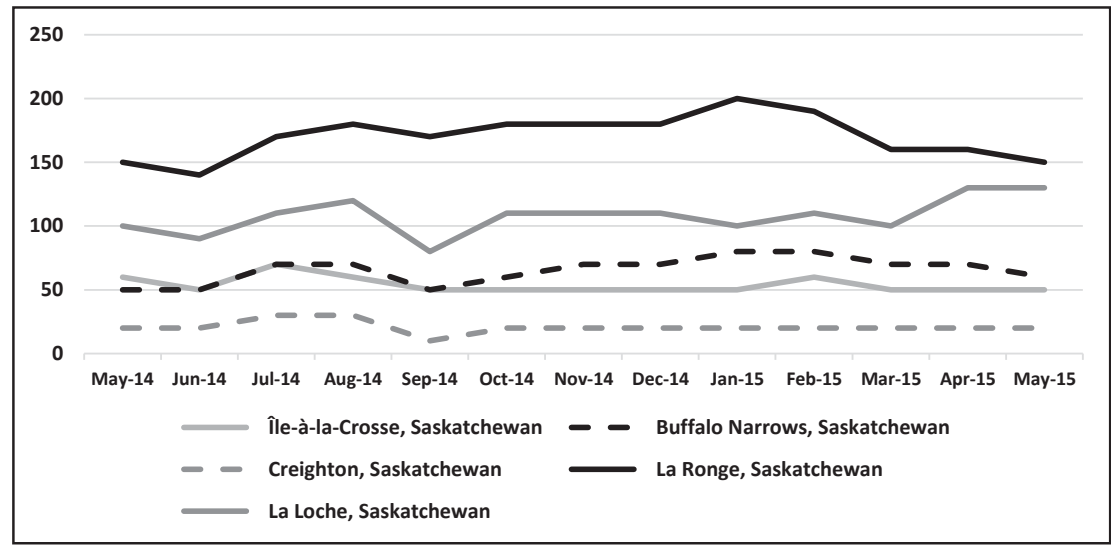

Figure 5. Number of workers on Employment Insurance, 2014-2015 


\section{Employment by Occupation}

The census data on employment by occupation and by industry are fairly consistent between 2001 and 2006 and provide breakouts by occupation and industry of employment as well as by sex. Between 2001 and 2006, there was an increase of 75 workers listed by occupation, with the largest increase in occupations unique to the trades, transportation, and equipment operations with 45 new workers, and with 25 new workers in the social sciences, education, and government category (see Table 8). Smaller gains were also made in the fields of arts, culture, and recreation; sales and services; as well as in primary industries. The 15 new workers in the arts, culture, and recreation sector is somewhat of a breakthrough for a northern Saskatchewan community. There were 20 fewer workers in management positions, as well as 10 fewer in business, finance, and administrative occupations - two occupational categories that would grow in an improving economy, not decline. In these areas, wages and salaries would generally be above average, so their loss is problematic. Northern communities generally have major gaps in the occupational codes, but for a northern Aboriginal community, Île-à-la-Crosse appears to have a diversified occupational breakout as of 2006, with only one category of workers missing (manufacturing and utilities).

Table 8. Comparison of occupations, île-à-la-Crosse 2001 to 2006

\begin{tabular}{lrrr}
\hline Occupations & 2006 & 2001 & Change \\
\hline Total experienced labour force 15 years \& over & 440 & 365 & 75 \\
A. Management occupations & 10 & 30 & -20 \\
B. Business, finance \& admin. & 30 & 40 & -10 \\
C. Natural and applied sciences & 10 & 15 & -5 \\
D. Health occupations & 45 & 35 & 10 \\
E. Social science, education, government \& religion & 85 & 60 & 25 \\
F. Art, culture, recreation \& sport & 15 & 0 & 15 \\
G. Sales \& service occupations & 100 & 85 & 15 \\
H. Trades, transport \& equipment operators & 80 & 35 & 45 \\
I. Primary industry & 55 & 45 & 10 \\
J. Manufacturing and utilities & 0 & 0 & 0 \\
\hline
\end{tabular}

Source: Statistics Canada, Census of Canada, 2001 and 2006 
The difference in male and female occupational participation is illustrated in Figure 6. Men dominated all positions in the primary industries (trades, transportation and equipment operations, and natural resources), while women hold more positions related to management; business and finance; arts, culture, and recreation; and health. Both males and females are represented in the education, social sciences, government services, and religion category (50 females and 35 males), as well as in sales and services ( 65 females and 40 males). The major difference between 2001 and 2006 was the loss of all male workers in management, which had stood at 25 in 2001.

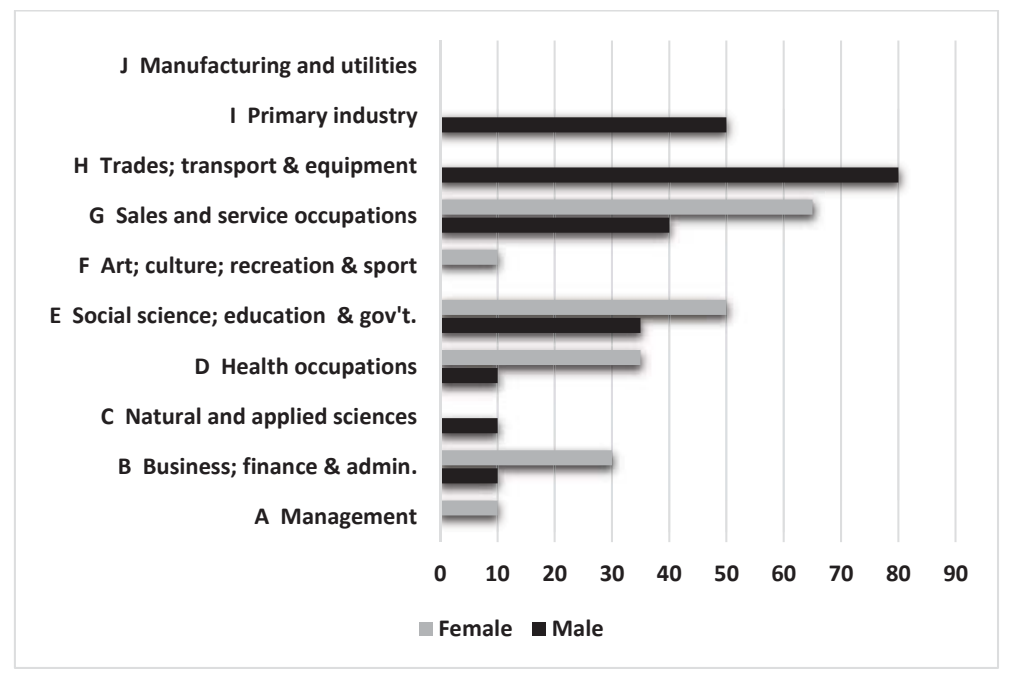

Figure 6. Île-à-la-Crosse occupations by gender, 2006

Earning and Incomes, 2000-2005

The Census of Canada measures the incomes of households and of individuals (over the age of 15). Between 2000 and 2005, the number of people with earnings in Île-à-la-Crosse increased from 665 to 750, or by $13 \%$. Median incomes (not adjusted for inflation) rose between 2001 and 2006 , from $\$ 14,400$ to $\$ 21,010$, an increase of $45.9 \%$ (Table 9). The community's median income is more than twice that of most First Nation reserve communities. The Buffalo Dene Nation, a neighbouring reserve community, for example, has a median income of only $\$ 10,272$, while Buffalo Narrows had a median income at just under $\$ 25,000$. This was actually above the provincial median of $\$ 23,755$ (Table 10 ). 
Table 9. Median incomes of individuals, Île-à-la-Crosse 2000 to 2005

\begin{tabular}{lrr}
\hline Category & 2005 & 2000 \\
\hline Median Income & $\$ 21,010$ & $\$ 14,400$ \\
Percentage Change & $45.9 \%$ & \\
\hline Source Statistics Canada NHS 2011, Census 2006 and 2001
\end{tabular}

Source: Statistics Canada NHS 2011, Census 2006 and 2001

Table 10. Comparisons of median incomes in Northern Saskatchewan, 2005

\begin{tabular}{lccrr}
\hline Category & Saskatchewan & $\begin{array}{c}\text { Buffalo } \\
\text { Narrows }\end{array}$ & $\begin{array}{l}\text { lle a la } \\
\text { Crosse }\end{array}$ & $\begin{array}{l}\text { Buffalo River } \\
\text { Dene Nation }\end{array}$ \\
\hline Median income $(\$)$ & $\$ 23,755$ & $\$ 24,848$ & $\$ 21,010$ & $\$ 10,272$ \\
\hline
\end{tabular}

Source: Statistics Canada Census of Canada 2006, Community Profiles

Figure 7 plots community median income against the median age of the northern communities and finds a weak positive correlation. What is more interesting about the plot is the clustering of the three representative communities groupings-First Nation in the lower left quadrant; nonAboriginal communities (two from the North along with a random selection of small and rural, southern Saskatchewan communities) cluster in the upper right quadrant; and occupying the middle ground between these two extremes are Métis communities including Île-à-la-Crosse.

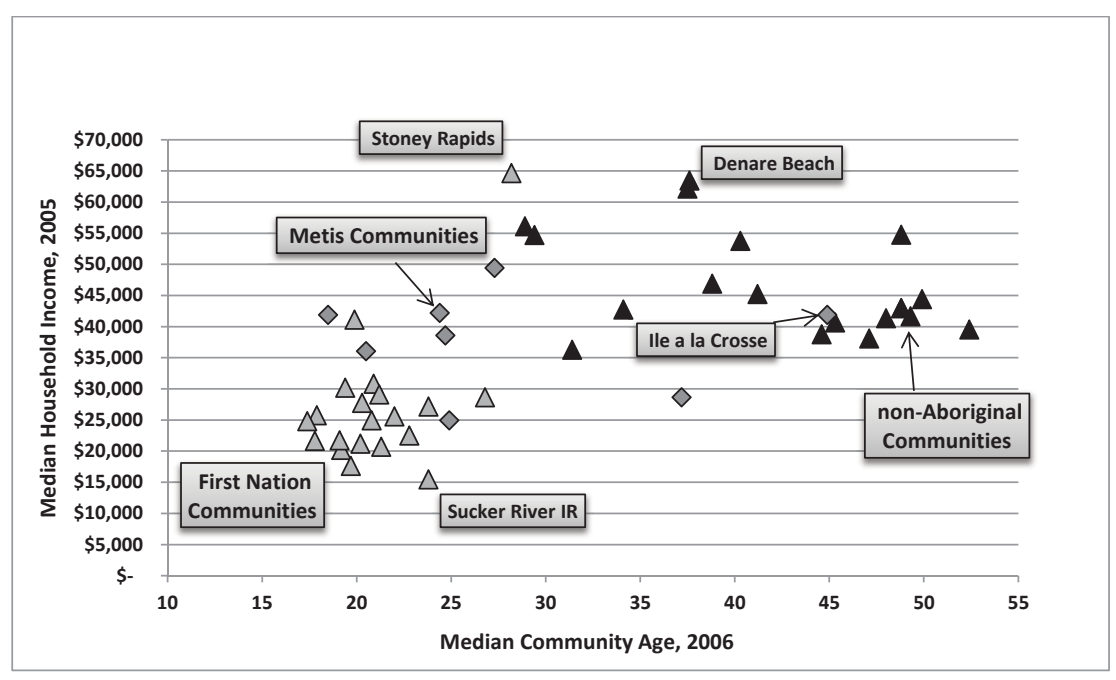

Figure 7. Median household income 2005 plotted against median household age, 2006 
Data for how households acquire their income is also available between the years 2000 and 2005, allowing us to assess the level of dependency on government transfer payments, be it welfare or pensions. During this period, the composition of the wage economy demonstrated a steady increase in market income and a slight decline in dependency on government transfer payments (Table 11). In contrast to the province as a whole, Île-à-la-Crosse had a somewhat lower percentage of its income composed of market earnings at $73.7 \%$ in 2005 compared to $88.5 \%$ for Saskatchewan. Overall, Île-à-la-Crosse illustrates a weaker market economy as measured by composition of income, and a higher level of dependency on government transfer income at $23 \%$ compared to $13 \%$ for the province in 2005.

Table 11. île-à-la-Crosse, 2010 composition of total income of population 15 years and over (\%) compared

\begin{tabular}{|c|c|c|c|c|c|c|}
\hline Census Income & \multicolumn{3}{|c|}{ île-à-la-Crosse } & \multicolumn{3}{|c|}{ Saskatchewan } \\
\hline Category & 2010 & 2005 & 2001 & 2010 & 2005 & 2001 \\
\hline Market income (\%) & ND & 73.7 & 67.3 & 88.5 & 73.9 & 73.6 \\
\hline $\begin{array}{l}\text { Government transfer } \\
\text { payments (\%) }\end{array}$ & ND & 22.8 & 30.5 & 11.5 & 12.8 & 14.7 \\
\hline Other Income (\%) & ND & 3.4 & 1.7 & NA & 13.3 & 11.7 \\
\hline
\end{tabular}

Source: Statistics Canada, Census of Canada, 2001, 2006; NHS 2011

Note: Due to random rounding, columns may not equal $100 \%$

This is further illustrated in Figure 8, which shows median community income and the percentage of each community's income derived from government transfers for 2005. Once again, First Nation communities, especially those on reserve, cluster in the upper left quadrant with low incomes and a high dependency on government transfers. In contrast, Métis communities are generally better off financially than First Nations, while the few northern non-Aboriginal communities such as Creighton and Denare Beach (along with the sample of small southern Saskatchewan communities) cluster in the low dependency/higher income lower righthand quadrant. 


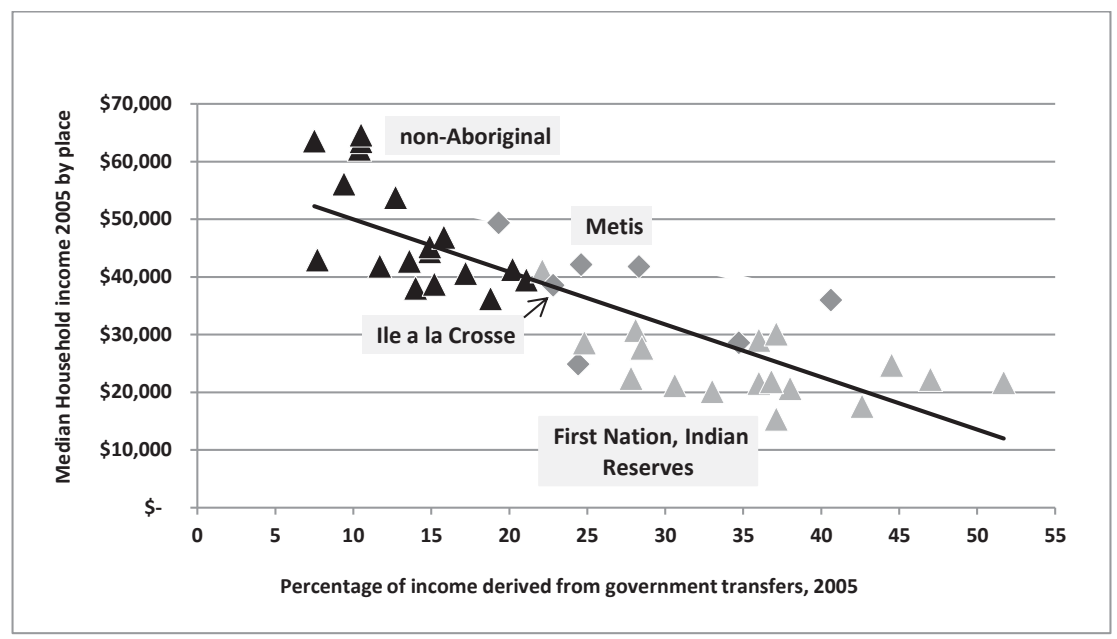

Figure 8. Correlation of median household income against percentage of income derived from government transfers, 2005, by ethnic majority

Table 12 compares the percentage of the population with low incomes across a selection of geographies, using 2006 Census data based on the 2005 tax year. The 2005 financial data indicates that $25.5 \%$ of the Île-àla-Crosse population was living in a low income situation (before taxes), which is considerably higher than the provincial count of $14 \%$ or that of neighbouring Buffalo Narrows at $16 \%$. Child poverty metrics are also available for 2005 , with Île-à-la-Crosse having $27 \%$ of its youth living in low-income situations compared to $18 \%$ for the province as a whole. These concepts of low income and dependency on government transfers are also reflected in capacity challenges as measured by low educational attainment, single parent families, health problems, and food scarcity.

Table 12. Income status of all persons in private households with low income, 2005

\begin{tabular}{lcccc}
\hline & $\begin{array}{c}\text { Île-à-la- } \\
\text { Crosse }\end{array}$ & La Loche & $\begin{array}{c}\text { Buffalo } \\
\text { Narrows }\end{array}$ & Saskatchewan \\
\hline Population & 1,335 & 2,340 & 1,080 & 897,575 \\
\% in low income before tax : & 25.5 & 29.9 & 16.2 & 14.4 \\
$\quad$ All persons, 2005 & & & & 18.1 \\
$\begin{array}{r}\text { \% in low income before tax: Persons } \\
\text { less than 18 years of age, 2005 }\end{array}$ & 27.3 & 34.1 & 18.1 & \\
\hline \multicolumn{2}{l}{ Source: Statistics Canada, Census of Canada, île-à-la-Crosse, 2006 } \\
\hline
\end{tabular}




\section{Education}

Both human capital and correspondence theories imply that an effective anti-poverty strategy should incorporate the enhancement of education and skills among households as there seem to be significant linkages between poverty and education. ${ }^{21}$ In remote communities, this relationship may actually be exacerbated by success-improving educational attainment usually requires students to travel to urban centres to attend postsecondary education institutions (although distance-learning programs may alleviate this problem). In so doing, students leave their community, often permanently, resulting in a declining pool of skilled workers in those communities. As a result, the ASI uses the proportion of graduates who are still in the community ten years later as a key indicator.

Across the Canadian North, it is difficult to acquire solid time-series data on the three recommended educational indicators: 1) the proportion of the population pursuing post-secondary education (not available); 2) the proportion with tertiary level degrees (available); and 3) the proportion of graduates who are still in the community ten years later (not available). Two other key indicators can be used: graduation rates and school attendance figures. Graduation rates provide a national standard against which to compare the educational attainment of Northern Saskatchewan youth. School attendance, likewise, is a good indicator for the cultural response of a community to education. If the children are not in school, the responsibility falls on the parents as well as the community, and not just the schools. ${ }^{22}$

Île-à-la-Crosse Educational Attainment

As of 2006, nearly 50\% of the Île-à-la-Crosse population had very little formal education, and had not graduated from high school. The proportion of the population with only high school graduation stood at $20.5 \%$. This means that only $30.1 \%$ of the people in the community 15 years of age and over had achieved some level of higher educational experience in the trades, college, or university, compared to $43 \%$ for Saskatchewan as a whole and $44 \%$ for Prince Albert. Educational attainment was substantially below the provincial average. This is a negative indicator of community capacity and resilience in a world that is increasingly driven by a specialist economy (Table 13). ${ }^{23}$ 
Table 13. Île-à-la-Crosse Educational Attainment by Sex, Census 2006

\begin{tabular}{|c|c|c|c|c|c|c|}
\hline Category & $\begin{array}{l}\text { Total } \\
\text { Pop. }\end{array}$ & As a $\%$ & Male & As a\% & Female & As a $\%$ \\
\hline $\begin{array}{l}2006 \text { Total population } 15 \\
\text { years and over }\end{array}$ & 880 & & 475 & & 410 & \\
\hline $\begin{array}{l}\text { No certificate; diploma } \\
\text { or degree }\end{array}$ & 440 & $50.0 \%$ & 250 & $52.6 \%$ & 190 & $46.3 \%$ \\
\hline $\begin{array}{l}\text { High school certificate } \\
\text { or equivalent }\end{array}$ & 180 & 20.4 & 60 & 12.6 & 115 & 28.1 \\
\hline $\begin{array}{l}\text { Apprenticeship or } \\
\text { trades cert. or dipl. }\end{array}$ & 155 & 17.6 & 105 & 22.1 & 55 & 13.4 \\
\hline $\begin{array}{l}\text { College; other non- } \\
\text { university cert. or dipl. }\end{array}$ & 50 & 5.7 & 25 & 5.3 & 25 & 6.1 \\
\hline $\begin{array}{l}\text { University cert. or dipl. } \\
\text { below BA level }\end{array}$ & 30 & 3.4 & 20 & 4.2 & 10 & 2.4 \\
\hline $\begin{array}{l}\text { University certificate; } \\
\text { diploma or degree }\end{array}$ & 30 & 3.4 & 15 & 3.2 & 15 & 3.7 \\
\hline
\end{tabular}

We can also access educational attainment from the 2006 Census data on "No Certificate" through to "University Degree." In Île-à-la-Crosse, men comprised a higher number of the early high-school leavers at 250 compared to 190 for females, with 115 females completing at least high school, compared to 60 males. Those males who finished high school appear to have moved forward with their education to attain apprenticeship or trades certificates or diplomas. However, once beyond trade school, few local residents appear to have acquired tertiary level degrees at college or university, with 25 males and an equal number of females acquiring some form of college diploma, and 15 each completing university degrees. This represents $3 \%$ of the population in 2006 compared to $12 \%$ for Prince Albert and $13 \%$ for the province.

\section{The Relationship between Education and Employment}

Cross-referencing education and employment is the natural bridge between the material well-being and education domains. It is generally recognized that there is a direct correlation between education and employment, with those workers who have higher levels of educational attainment having workforce participation rates and employment rates that are considerably better than workers with "No certificate." 
The 2006 Census cross-tabulations for education against labour force activity are publicly available online for most communities (Table 14). With a 2006 labour force of 885 people 15 years of age and older, of whom only 445 were actively involved in the labour force, and with a low participation rate at $51 \%$, there is a strong correlation between employment and education as expected. In 2006, an incredibly high percentage of the labour force population, $50 \%$, were listed as being "Not in the labour force" (NILF), the vast majority of whom failed to complete high school. Those lacking a high school certificate, a diploma, or a degree had an unemployment rate of $20 \%$ and a participation rate of only $28 \%$, meaning that 315 of these 440 early school-leavers were not working or even looking for work. In the community, participation rates improve with education, with the participation rate standing at $57 \%$ for high school graduates and $74 \%$ for those holding apprenticeship or trades certificates, and rising to $100 \%$ for workers with some level of college or university education. The numbers for university are very small, with only 30 workers apparently active in the labour force and employed. It is not known if they are local residents or professionals who moved to the community to take positions in education and health on short-term contracts.

The review of education indicators identifies major limitations that make the community less than market ready for development. A major concern is that the new jobs being created by mining firms, as well as in more modern diversified sectors of the economy, create further educational/labour problems in the community such as:

- Those with skills and ability are attracted away from existing, often essential jobs in the community to work at the mines;

- Young people leave school before graduating in order to tap into high-paying, low-skill-level jobs at the mines, forfeiting their future for a short-term financial gain;

- Residents who suffer from chronic unemployment do not have the education and skills required to get a job in the resource sector. 
Table 14. Labour Force Activity, cross-tabulated to highest certificate, diploma, or degree attained, for the Île-à-la-Crosse population 15 Years and older, 2006 Census

\begin{tabular}{|c|c|c|c|c|c|c|c|c|}
\hline & 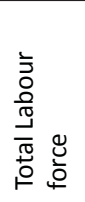 & 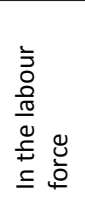 & 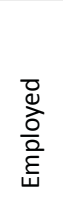 & 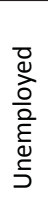 & 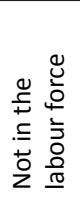 & 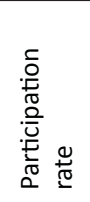 & 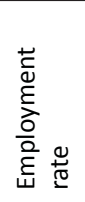 & 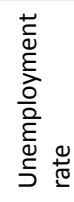 \\
\hline $\begin{array}{l}\text { Total, Highest } \\
\text { certificate, diploma } \\
\text { or degree }\end{array}$ & 885 & 455 & 400 & 55 & 425 & 51.4 & 45.2 & 12.1 \\
\hline $\begin{array}{l}\text { No Certificate/ } \\
\text { Degree }\end{array}$ & 440 & 125 & 100 & 25 & 315 & 28.4 & 22.7 & 20 \\
\hline $\begin{array}{l}\text { High school certifi- } \\
\text { cate/equivalent }\end{array}$ & 175 & 100 & 100 & 10 & 75 & 57.1 & 57.1 & 10 \\
\hline $\begin{array}{l}\text { Apprenticeship or } \\
\text { trades certificate/ } \\
\text { diploma }\end{array}$ & 155 & 115 & 105 & 10 & 40 & 74.2 & 67.7 & 8.7 \\
\hline $\begin{array}{l}\text { College or other } \\
\text { non-university } \\
\text { diploma }\end{array}$ & 55 & 55 & 50 & 0 & 0 & 100 & 90.9 & 0 \\
\hline $\begin{array}{l}\text { University below } \\
\text { bachelor level }\end{array}$ & 30 & 30 & 15 & 15 & 0 & 100 & 50 & 50 \\
\hline $\begin{array}{l}\text { University degree } \\
\text { at BA or above }\end{array}$ & 30 & 30 & 30 & 0 & 0 & 100 & 100 & 0 \\
\hline
\end{tabular}

International Skills Survey and Northern Saskatchewan

Comparative measures of three foundational skill sets in the populations of thirty-three countries was undertaken in 2013 by the Programme for the International Assessment of Adult Competencies (PIACC), which is an agency of the Organization for Economic Co-operation and Development (OECD). Data has been released for Canada with breakouts of Aboriginal and non-Aboriginal populations. The findings for Aboriginal Saskatchewan are striking. In Saskatchewan, 33\% of the Aboriginal population are operating at Level 1 or below (Table 15), which the assessment defines as:

Level 1: these individuals have skills that enable them to undertake tasks of limited complexity, such as locating single pieces of information in short texts in the absence of other distracting information. Those categorized as "below Level 1," do not command these skills. ${ }^{24}$ 
This does not bode well for northern workers as mining is becoming increasingly mechanized, robotic, and innovation-driven and, as such, is requiring higher levels of education, training, and skills.

Table 15. Composite PIACC average scores, Northern Saskatchewan, Canada, and the OECD, 2012

\begin{tabular}{lccc}
\hline Region & $\begin{array}{c}\text { Literacy } \\
\text { Average } \\
\text { Score }\end{array}$ & $\begin{array}{c}\text { Numeracy } \\
\text { Average } \\
\text { Scores }\end{array}$ & $\begin{array}{c}\text { PS-TRE Average } \\
\text { Level 1 or below } \\
\text { and } \\
\text { Non-respondents }\end{array}$ \\
\hline OECD Countries & 273.3 & 269.4 & 66.0 \\
Canada & 273.5 & 265.5 & 57.4 \\
Yukon & 277.2 & 263.1 & 64.3 \\
NWT & 253.3 & 239.4 & 71.7 \\
Nunavut & $219.1 *$ & $200.5 *$ & 88.2 \\
Aboriginal Saskatchewan & 248.2 & 231.6 & 78.7 \\
\hline $\begin{array}{l}\text { Source: Statistics Canada: Catalogue no. 89-555-X ISBN 978-1-100-22678-1, Skills in } \\
\text { Canada: First Results from the Programme for the International Assessment of Adult } \\
\text { Competencies (PIAAC) } \\
\text { *Lowest scores in OECD PIACC Test, 2012 }\end{array}$ \\
\hline
\end{tabular}

\section{Health and Well-Being}

When assessing health-based indicators, there is considerable gathering and reporting on negative health outcomes, ranging from teenage pregnancies, to high infant mortality, through to poor self-rated health. As the communities in the North are generally small and the level of knowledge about each other is high, reporting agencies generally roll up data at the regional level to ensure anonymity, as well as due to the need to have representative populations for reporting. This, of course, limits the ability to apply and assess the ASI recommended socio-economic indicators on health. The community of Île-à-la-Crosse is in the Keewatin Yatthé Heath Region, a region with a small population and low population density spread over a vast expanse of northwestern Saskatchewan, which hampers the effective delivery of medical services. ${ }^{25}$

The two main proxy measures of the health and status of a community, as recommended for use by the ASI, are infant mortality rates and outmigration. The infant mortality rate is reported some three to four years prior to the current date, while birth estimates are reported annually with 2011-2012 being the current year. 
Infant Mortality Rates and Teen Pregnancy

Infant mortality is covered in The Health of Canada's Children, Part 1 (2010), which presents a comprehensive analysis of infant mortality rates in Canada and explains why they are still so high in many jurisdictions such as Nunavut (10 deaths per 1,000 births) and Saskatchewan (8.3) (2008 data). Health experts often note that the single best indicator to represent the health of the population is infant mortality. ${ }^{26}$ Infant mortality is a proxy measure for parental education as well as for the ability of the state to provide health and safety. Where high infant mortality occurs we can assume that the state is partially at fault for failing to deliver these services or the educational support parents require in these communities. The North also suffers from high teen pregnancy rates, which are related to the higher occurrence of infant mortality (Figure 9). Comparing the infant mortality rate in Northern Saskatchewan with other Canadian northern regions, we see that the three-year average northern Saskatchewan rate of 9 infant deaths per 1,000 live births is lower than rates in Nunavik in northern Quebec $(21 / 1,000)$, but higher than rates for Saskatchewan $(6 / 1,000)$ and the Canadian average of 5/1,000 live births. Between 20002002 and 2005-2007, the three-year average rate in northern Saskatchewan improved from 11.5 to 9 infant deaths per 1,000 births. ${ }^{27}$

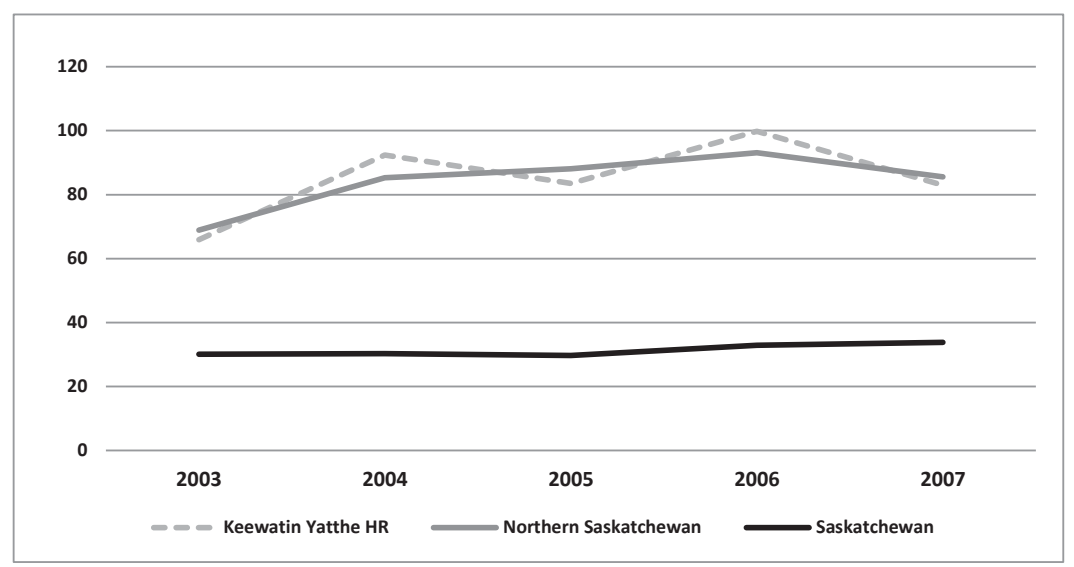

Figure 9. Teenage pregnancies per 1,000, aged 14-19, Saskatchewan South and North 
Population Indicators, Out-Migration

One of the ASI's key indicator on community cohesion is the measurement of out-migration. Unfortunately, out-migration is not one of Statistics Canada's ordinarly published data sets, so it requires that a special request be made to Statistics Canada for the data on out-migration; as such, this is a pay-for-service data set. ${ }^{28}$ Out-migration, once calculated, will allow us to build up a profile of those who leave the community. This would be especially useful for assessing community capacity. ${ }^{29}$

\section{Cultural Well-Being and Vitality}

"Cultural integrity" is defined as the ability of a culture to retain fundamental elements over time (ADHR 2004). The dimensions of culture domain can be seen to include language and its use and retention; traditional knowledge and its transmission; communication of culture; and spirituality as well as social events and networks. ASI indicators for cultural vitality include the following:

- The percentage of a population that speaks its ancestral language, compared with the language retention of the population as a whole;

- The percentage of the population that is engaged in recreational or subsistence activities or displays a sense of "belonging on the land"; and

- The relative size of the informal (subsistence-based) sector of the economy.

Once again, though, there is no 2011 information, but data is available from the 1996, 2001, and 2006 censuses.

In the realm of the qualitative social indicators, the ability of the census or administrative data to speak to the ASI recommended indicators weakens. This is particularly the case with cultural well-being and vitality in Aboriginal communities that have been impacted not only by the longterm effects of the residential schools system and other social and health related issues, but also by the predominance of English language usage in western Canada. In Île-à-la-Crosse, it is not clear from recent census records if English would have been the mother tongue of the local Métis population, or if they were originally French or Michif speakers. Michif is a unique language expressing Métis understandings of the world, in which they live in both the colonial and the Indigenous languages, and was created in the homes and lives of Métis peoples (Iseke, 2013, 96). From the 2011 Census we know that Michif was still spoken in a scattering of 
Métis communities in western Canada, with 640 speakers of whom $40.6 \%$ lived in Saskatchewan. ${ }^{30}$ Tom McCallum, who was born and raised in Îleà-la-Crosse and who is fluent in Nêhiawuk (Cree) and Michif explains the way the language shaped his way of seeing the world (Iseke, 2013, 100-103):

You see before the Europeans came here, we were Nehiyawak. After the Europeans came here we were no longer Nehiyawak, we turned out to be Cree. ... Because of the way we speak is the way we think. ... But when you speak English you're thinking in an English perspective. I know that's the language that we all use. ... A lot of us don't know any other language. We know the English language, that's all. And that's not a feeling language. It's not a verb-based language, a feeling language, like the Aboriginal language.

Again, further community-level research on fate control, as this pertains to culture, local control, and management of resources, needs to be explored in the community.

\section{Language Use}

The census provides one of the better time-series data sets for tracking language use such as mother tongue, official language, home language use, and language used at work. As noted in Figure 1, Île-à-la-Crosse is predominately an Aboriginal community with $92.5 \%$ declaring Aboriginal heritage in 2006. From the 2011 Census language data we see that of the 1,270 single responses, 965 people spoke English as their mother tongue. Only five spoke French while some 205 spoke an Aboriginal language. Of the latter, 200 of these were Cree speakers and 5 were Dene speakers. Unexpectedly, the census includes 80 people who speak an "Other" language; these are individuals who replied that they speak English or French plus a non-official langauge. These could be Michif speakers. ${ }^{31}$

In 2011, we see a considerable decline in Cree (home language) when compared to Cree (mother tongue), with a decline of $72.5 \%$ (Table 16). The weakening of Aboriginal mother tongues is generally seen as an indicator of cultural assimilation, with the Aboriginal language losing speakers to the dominant colonial language. In this case, using 1996 data demonstrates how this transition to English occurred (Table 17). 
Table 16. Aboriginal language continuity, île-à-la-Crosse 2011

\begin{tabular}{lccc}
\hline & $\begin{array}{c}\text { Total } \\
\text { Population }\end{array}$ & Male & Female \\
\hline Total Cree Mother Tongue Population & 200 & 100 & 100 \\
Total Cree Home Language Population & 55 & 30 & 20 \\
Decline, in percent & $-72.5 \%$ & $-70 \%$ & $-80 \%$ \\
\hline Source: Statistics Canada Census of Canada, 2011 & & \\
\hline
\end{tabular}

Table 17. 1996 Language vitality indicator, île-à-la-Crosse, Census 1996

\begin{tabular}{lcccc}
\hline (A) Language & $\begin{array}{c}\text { (B) Speakers } \\
\text { mother language } \\
\text { single response }\end{array}$ & $\begin{array}{c}\text { (C) Speakers } \\
\text { home language, } \\
\text { single response }\end{array}$ & $\begin{array}{c}\text { (D) } \\
\text { Linguistic } \\
\text { persistence } \\
\text { and } \\
\text { attraction }\end{array}$ & $\begin{array}{c}\text { (E) } \\
\text { Linguistic } \\
\text { vitality } \\
\text { indicator }\end{array}$ \\
\hline English & 840 & 1050 & 210 & 1.25 \\
Cree & 460 & 230 & -230 & 0.5 \\
\hline Source: Calculated by author, Statistics Canada. Census of Canada, 1996 & \\
\hline
\end{tabular}

Traditional Arts and Culture Practices and Employment

Beginning with the artists' co-op movement of the early 1960s, Inuit carvers and printmakers in Canada became a world-wide phenomenon, projecting their images and understandings of the Arctic internationally. This has allowed some Nunavut communities to become hives of artistic production, while supporting economic diversification. Canada's arts community was captured in the 2007 study Towards Geography of Culture: Culture Occupations across the Canadian Urban-Rural Divide, 2001. This study, covering 399 unique geographies, ranked artistic communities across Canada-but, importantly, it found no communities in Northern Saskatchewan that had a measureable arts community.

\section{Fate Control}

Fate control is a people's ability to guide their own destiny. While the literature on fate control with respect to North American First Nations is scant, the concept is associated with the more common term "empowerment" - the process of achieving the capacity to "make choices and then to transform those choices into desired actions and outcomes" (Ibrahim and Alkire, 2007). Fate control is the outcome of empowerment 
and runs counter to colonialism or internal colonialism, whereby distant corporate investors and national-capital decision-makers decide the fate of northern people. Increasing levels of self-government across the North represent a move towards improved fate control (Finnegan, 2013). Research on the fate control domain includes the following topics:

- Elected officials: Proportional representation by ethnicity ${ }^{32}$;

- Control over land management;

- The percentage of public expenses within the region raised locally; and

- The sense of belonging to community.33

We can readily find evidence to support all of the above, either directly or through proxy measures, with the exception of the percentage of public expenses raised within the region-although dependency on government transfer payments serves as a proxy measure for this indicator, as discussed above, with the community of Île-à-la-Crosse decreasing its dependency on government transfers between 1996 and 2006.

\section{Land Management}

A key fate control measure is the percentage of surface lands legally controlled by the inhabitants through public governments, land management boards or councils, and/or Native corporations. These differ across northern Canada based on land claim settlements, the size of the community, and the effectiveness of the negotiations. Secondly, land management is an outgrowth of policy and planning. The more effectively a local government operates, the more it is able to advance land management planning to its advantage. Once again, the percentage of land under control, or the amount of land under control per person, speaks to decision-making power and the exercise of human rights. This type of assessment requires discussions with land managers in the community. As Île-à-la-Crosse is a Northern Village, local land management will be less compromised by the need to defer to "Ottawa" (the federal government) on land use decisions, with the Saskatchewan provincial government in Regina playing a larger role in community planning.

The community has posted an extensive array of land use planning documents at the Planning for Growth Program website, ${ }^{34}$ which speaks to an active socio-economic and environmental planning process and, as such, to an effective fate control process - although only two of the studies are recent products (circa 2011). The website highlights three current 
studies-including a housing study by the Primrose Lake Economic Development Corportation, the Editing of the Official Community Plan and Zoning Bylaw, and a Community Consultation process-as components of the Planning for Growth North Program.

As a Northern Village, property in Île-à-la-Crosse is owned in fee simple, unlike on reserves where the land is owned by the Crown. ${ }^{35}$ Dwellings in northern hamlets and villages may be owned by the residents and, as such, form personal wealth that can act as collateral for investment purposes. Tables 18 and 19 show ownership and average value of dwellings through time from 2001 to 2006, and compare Île-à-laCrosse with Buffalo Narrows and the province as a whole. Between 2001 and 2006, there was a small increase in the number of dwellings in the community, rising from 365 to 405 ; but there was also a move towards home ownership, increasing from 175 in 2001 to 195 in 2006. Housing rentals increased by only five units, from 195 to 200, suggesting that new housing stock was being built-to-own. By 2006, 48\% of dwellings were owned in the community, which falls short of the provincial average of $72 \%$. Housing values soared between 2001 and 2006, with an increase of over 34\% after a sluggish market valuation between 1996 and 2001, which actually saw housing values barely move from an average value of $\$ 43,492$. The 2006 dwelling values in the community were substantially below those of neighbouring Buffalo Narrows $(\$ 64,732$ compared to $\$ 97,359)$, and well short of the provincial average $(\$ 132,111)$.

Table 18. Housing Market, Île-à-la-Crosse 2001 to 2011

\begin{tabular}{lrrr}
\hline & 2011 & 2006 & 2001 \\
\hline Total number of dwellings & Suppressed & 405 & 365 \\
Number of owned dwellings & 195 & 175 \\
Number of rented dwellings & 200 & 195 \\
Average value of dwelling $(\$)$ & $\$ 64,732$ & $\$ 48,321$ \\
Percentage Increase & $33.7 \%$ & \\
\hline
\end{tabular}

Source: Statistics Canada: Census of Canada, 1996, 2001, 2006 and NHS 2011 Based on the 1996 Census figure for average of $\$ 43,887$. 
Table 19. Housing market, île-à-la-Crosse and Buffalo Narrows, 2006

\begin{tabular}{lccc}
\hline & île-à-la-Crosse & $\begin{array}{c}\text { Buffalo } \\
\text { Narrows }\end{array}$ & Saskatchewan \\
\hline Total number of dwellings & 405 & 375 & 387,140 \\
Total owned dwelling & 195 & 235 & 277,860 \\
Percentage owned dwellings & $48 \%$ & $63 \%$ & $72 \%$ \\
Total rented dwellings & 201 & 145 & 99,125 \\
Percentage rented dwellings & $50 \%$ & $39 \%$ & $26 \%$ \\
Average value of dwelling (\$) & $\$ 64,732$ & $\$ 97,359$ & $\$ 132,111$ \\
\hline Source: Statistics Canada: NHS 2011 & & & \\
\hline
\end{tabular}

Food Security

A less abstract measure of fate control is food security. Northern communities fare poorly on fate control as measured by the food security indicator. The finding of recent Canadian Community Health Surveys (CCHS) indicates that in the three northern health regions of the province, moderate to severe food insecurity was endured by $9 \%$ of the population in 2007-2008 compared to $6 \%$ for the province. That number rose to $13 \%$ in $2011-2012$, or an increase of $38 \%$, while just $8 \%$ of the provincial population reported food insecurity (Tables 20 and 21). The problem of food security is even further exacerbated by food security for the age cohort 12-19, which includes teenage parents. Here, food security has worsened. A full $25 \%$ of the youth population reported food insecurity as moderate to severe between 2008 and 2012 in the three northern health regions (Mamawetan Churchill River, Keewatin Yatthé, and Athabasca).

The prevalence of food insecurity was lower in households where post-secondary graduation was the highest level of education achieved (6\%), compared with less-than-secondary-graduation (14\%). ${ }^{36}$ The food security problem is exacerbated by the remoteness of the communities, the high cost of transport, and the resulting high cost of foodstuffs. ${ }^{37}$ Statistics Canada reports that 29\% of northern Saskatchewan households have either moderate or severe food insecurity issues, more than four times the Saskatchewan level. 
Table 20. Household food insecurity in Saskatchewan, age 12 and over, male and female, total number of persons in households

\begin{tabular}{|c|c|c|c|c|}
\hline \multicolumn{5}{|c|}{ Canadian Community Health Survey - Annual Component - 3226} \\
\hline & $\begin{array}{l}2011- \\
2012\end{array}$ & $\begin{array}{c}\text { As a } \\
\%\end{array}$ & $\begin{array}{l}2007- \\
2008\end{array}$ & $\begin{array}{c}\text { As a } \\
\%\end{array}$ \\
\hline Food secure & 759,106 & & 716,797 & \\
\hline $\begin{array}{l}\text { Food insecure, mod- } \\
\text { erate and severe }\end{array}$ & 61,005 & $8 \%$ & 43,948 & $6 \%$ \\
\hline \multicolumn{5}{|c|}{$\begin{array}{l}\text { Statistics Canada. Table } 105-0547 \text { - Household food insecurity, by age group and sex, } \\
\text { Canada, provinces, territories, health regions ( } 2013 \text { boundaries) and peer groups, occasional } \\
\text { (number unless otherwise noted). }\end{array}$} \\
\hline
\end{tabular}

Table 21. Food security in Mamawetan/Keewatin/Athabasca, Saskatchewan, by total number of persons in households, male and female

\begin{tabular}{|c|c|c|c|c|c|c|c|c|}
\hline & \multicolumn{4}{|c|}{ Total, 12 years and over } & \multicolumn{4}{|c|}{12 to 19 years } \\
\hline & 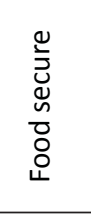 & 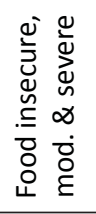 & $\frac{\dot{8}}{0}$ & 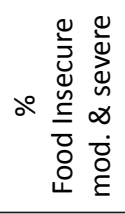 & 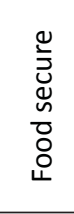 & 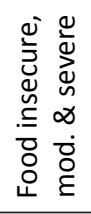 & $\frac{\dot{0}}{\frac{0}{0}}$ & 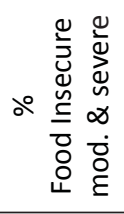 \\
\hline $\begin{array}{l}2007- \\
2008\end{array}$ & 8,565 & 876 & 9,441 & $9.3 \%$ & 512 & 170 & 682 & $24.9 \%$ \\
\hline $\begin{array}{l}2011- \\
2012\end{array}$ & 6,693 & 982 & 7,675 & $12.8 \%$ & 758 & 324 & 1,082 & $29.9 \%$ \\
\hline
\end{tabular}

Sense of Belonging to Community, Canada, and the North

The Canadian Community Health Surveyes also asks respondents about their sense of belonging to their community. Indicators for social environments include the strength of social networks within families and across the community, recognition and celebration of diversity and culture, civic participation and volunteerism, as well as a sense of belonging and safety (Public Health Agency of Canada, 2003). The Northern Saskatchewan rate for self-reported community belonging as "strong" or "very strong" increased to over $80 \%$ for 2010-2011 compared to the Saskatchewan rate of $73 \%$ (Table 22), which indicates the strength of family and communities ties in the region. 


\begin{tabular}{|c|c|c|c|}
\hline & $\begin{array}{l}2007- \\
2008\end{array}$ & $\begin{array}{l}2009- \\
2010\end{array}$ & $\begin{array}{l}2011- \\
2012\end{array}$ \\
\hline Canada & $64.8 \%$ & $65.4 \%$ & $65.4 \%$ \\
\hline Saskatchewan & 70.5 & 71.4 & 73.0 \\
\hline Northern Saskatchewan & 77.0 & 81.1 & 80.2 \\
\hline Nunavut & 82.2 & 86.6 & 83.5 \\
\hline
\end{tabular}

\section{Contact with Nature}

In pursuing the goal of "a diverse economy," the ASI recommend susing the percentage of the population who harvest for commercial use; sell fish meat carvings, or other goods and crafts; or bought and/or sold country food as indications of the strength of connection to nature. There is data on hunting, fishing, and trapping derived from the 2006 and 2012 Aboriginal Peoples Survey. Table 23 provides an overview of the change in participation in hunting, fishing, trapping, and gathering activities between 2006 and 2012 , with a drop of just over $10 \%$ in the frequency with which residents in Northern Saskatchewan were participating in these activities. However, this still left $67.4 \%$ of the 2012 population participating in these activities (Table 24). We can compare the 2006 hunting and gathering numbers for Northern Saskatchewan against the 2006 Aboriginal Peoples Survey for the Inuit Nunangat region, which reported $68 \%$ so engaged, compared to the $77.5 \%$ in the northern Saskatchewan census division (Census Division 18). This suggests the people in this region have even greater contact with nature than do the Inuit. 
Table 23. Aboriginal respondents who have hunted, fished, trapped, or gathered food in the last 12 months, within Census Subdivision 18

\begin{tabular}{lccrr} 
& \multicolumn{2}{c}{2012} & \multicolumn{2}{c}{2006} \\
& Number & $\%$ & Number & $\%$ \\
\hline Total & 2,850 & 100 & 3,110 & 100 \\
Yes & 1,920 & 67.4 & 2,410 & 77.5 \\
No & 730 & 25.6 & $\mathrm{~F}$ & $\mathrm{~F}$ \\
Don't Know/Not Stated/Refusal & $210^{\mathrm{E}}$ & 7.4 & $\mathrm{~F}$ & $\mathrm{~F}$ \\
\hline Notes & & & & \\
Counts may not add to 100\% due to rounding & & & \\
E Use with caution & & & & \\
F Too unreliable to publish & & & \\
Source: Statistics Canada, Aboriginal People's Survey, 2006 \& 2012 & & \\
\hline
\end{tabular}

Table 24. Aboriginal respondents who have hunted, fished, trapped, or gathered within the last 12 months, within Census Subdivision 18

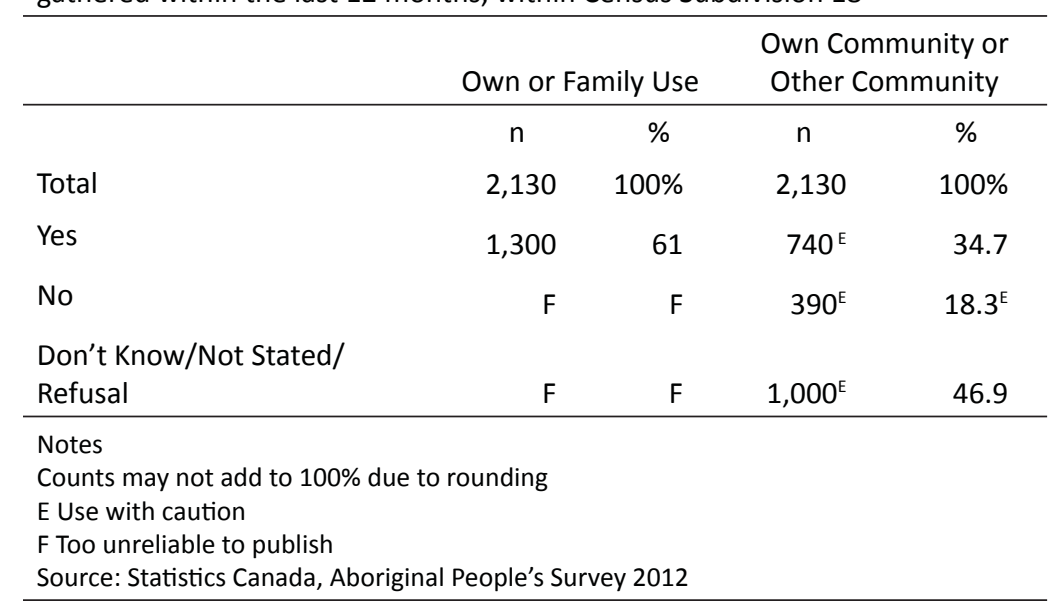




\section{Overall Assessment of the Community}

There is excellent census data by sex, age cohorts, and change through time on a five-year cycle. However, it is not possible, using the existing public databases, to drill down in small communities to look at internal migration patterns. Turning to material well-being, defined as a measure of local residents' command over goods and services, Île-à-la-Crosse lies on a continuum between its neighbours, especially Buffalo Narrows, the regional urban centre of Prince Albert, and the provincial averages. There is statistical evidence for the ASI indicators market income and government transfers, but not for subsistence, which very much addresses the dayto-day, behind-the-scenes workings of community life in a tightly knit northern community. This data cannot be accessed without community participation in a quality-of-life type of community survey. There is however, solid evidence using DRs that there has been an improvement in the ratio between the number of dependent children and seniors in the community compared to the number of working-age providers. This leads us into the measure of Housing, the single largest investment that families make in order to solidify their well-being. There is both direct and proxy measures of crowding, housing quality, and housing costs, as well as the value of that investment for home owners. We also have data on home ownership, average value of owned houses, and percentage of income spent on shelter from the census, although nothing more recent than 2006.

The labour market information available also indicates that there is good data to assess material well-being, and that Île-à-la-Crosse is one of the more active and engaged labour markets in northern Saskatchewan. These metrics provide solid evidence of the level of material well-being through comparisons between Île-à-la-Crosse, Buffalo Narrows, and other jurisdictions, indicating that Île-à-la-Crosse is comparatively better off than most of its northern neighbours. ${ }^{38}$

While there is considerable evidence to document the educational problems that exist in Île-à-la-Crosse due to low educational attainment and the subsequent underemployment, there is no data for two of the ASI required indicators-residents who are doing post-secondary education away from the community and, secondly, the proportion of the community's graduates who are still in the community ten years later. The one ASI indicator available is the proportion of people with postsecondary education. This is, again, a very low percentage regardless of how post-secondary education is counted, be it participation in, or completion of, studies. There is strong data related to high school graduation rates. Basically, they are very low. As well, low educational 
attainment impacts the labour market - if you don't complete high school, you probably won't find a job. Finally, when people of Aboriginal descent in northern Saskatchewan are compared to other Canadians and OECD member states using standardized competency testing, it is clear that the region's scores are in the lowest competency categories and not dissimilar to those from Nunavut.

To approximate the ASI indicators for health, it was necessary to substitute regional health authority data and/or Northern Saskatchewan data for our preferred community data. Secondly, there is no readily accessible data to measure out-migration, meaning that one of the two socio-economic indicators of community health is absent-this leaves only infant mortality, which is only available at the regional level. In order to improve the outcomes, life expectancy, teenage pregnancy, and selfrated health were added, once again only available at the regional level. Even so, these health indicators indicate that the region, and likely Île-àla-Crosse, is in need of considerable assistance, planning, and investment in health programs in order to improve the quality of life in Northern Saskatchewan.

With regard to cultural well-being and vitality, the core data sets available do not address the ASI indicators. There are some proxy measures of well-being available, such as language vitality, and the results show that the community is now solidly English speaking. We need to askwhat is the impact of this transition to English upon the culture of the community, and when did the transition to English occur? Clearly, more research needs to be carried out on arts and culture in the community, as well as on social and cultural well-being associated with subsistence hunting, fishing, and gathering.

The review of the data for the fate control domain indicates that a number of records can directly answer the questions posed by the ASI indicators, such as composition of income and sense of belonging, but that in other cases we need further community-led research to complete the profile for community fate control. For example, there is a legal duty to consult Aboriginal people when development is taking place on their lands. ${ }^{39}$ The assessment of income as an indicator of fate control provides mixed results. On the one hand, the community improved its proportion of market income, but still has high levels of child poverty. Poverty and low income are also reflected in the food security metric, which indicates that a rising proportion of the people in Northern Saskatchewan are having challenges feeding themselves. Finally, fate control also stresses 
the sense of belonging to one's community, which is generally found to be considerably higher in northern communities than in southern Canada.

\section{Conclusion}

Even with the suppression of the 2011 National Household Survey data for this community, Île-à-la-Crosse presents the case of a relatively data-rich environment for the application of the ASI model for assessing the impacts of development on Aboriginal people in Canada's provincial North. In most instances, community indicators could be developed that follow the recommendations of the ASI report for the domains of population and material well-being, as well as for one of the required education metrics. In some instances, proxy metrics had to be used to address the indicator. In some cases, it could be argued that the available Canadian data was more applicable than the suggested ASI recommendations. There is greater difficulty in finding community specific indicators for health, cultural well-being and vitality, and fate control. Within these domains, a mixture of community level data integrated with regional data from the existing sources was possible. In some cases, the recommended indicators could not be addressed in these three domains directly, relying alternatively on Canadian examples or proxy indicators. Finally, it was not possible to address the contact with nature domain indicators using publicly available data, regardless of geographic scale.

This report used the Arctic Social Indicators as a way to structure an assessment of the socio-economic indicators applicable for the development of community baselines studies, and to assess the state of human development in remote communities in Northern Saskatchewan. A wide range of ASI indicators can be applied in the review of human development for the community, which provide both temporal dimensions as well as geographically comparable data. As Petrov, King, and Cavin (2013) note: "The primary data challenge facing the application of ASI is the variability and evolving nature of definitions and data collection methods utilized by different sources, which complicate interregional and longitudinal analyses." As they show, the ASI indicators are suitable for monitoring human development in the Canadian provincial North. Clearly, sufficient data exists that can be applied to construct indicators for five of the six domains, while the contact with nature domain requires greater research and investment in order to acquire data.

The available statistical data provides important insights into Îleà-la-Crosse. The use of the Arctic Social Indicators 2010 creates an opportunity to compare this northern community to other communities 
in northern Saskatchewan as well as elsewhere in across the north-a more relevant comparison than the assessments against provincial and federal standards. The information tells us a great deal about Île-à-laCrosse in terms of education, housing, poverty, and the like, but statistical precision is not the same as deep understanding. There is a great deal that remains unknown about such topics as cultural retention, community empowerment vis-a-vis external decision making, and the nature of traditional harvesting activities. The data provide a means of evaluating the impact of the past and offer a foundation for developing strategies for the future. With this information, a more detailed portrait is emerging of the nature of Indigenous and non-Indigenous life in northern Canada. Expanding the Arctic Social Indicators work into the provincial North is an important step toward empowering communities to take greater control of their futures.

\section{Authors}

Greg Finnegan, $\mathrm{PhD}$ (Geography), is a research associate with the International Centre for Northern Governance and Development at the University of Saskatchewan, based in Whitehorse.

Ken Coates is a professor and Canada Research Chair in Regional Innovation in the Johnson-Shoyama Graduate School of Public Policy at the University of Saskatchewan.

\section{Notes}

1. See http://www.svs.is/images/pdf files/Arctic Social Indicators II May 2013-Ministerial Meetingv.pdf

2. Gahine, R., V. Velva \& M. Hart. 2003. “Do Indicators Help Create Sustainable Communities?" Local Environment 8(6): 661-666.

3. The data developed in this report could be used to design community dashboards that track a series of community-significant socio-economic variables that the community can monitor and influence through policy.

4. Proxy Measures: A proxy variable is a variable that is used to measure an unobservable quantity of interest. Although a proxy variable is not a direct measure of the desired quantity, a good proxy variable is strongly related to the unobserved variable of interest. Proxy variables are extremely important to, and frequently used in, the social indicators research because of the difficulty or impossibility of obtaining measures of the quantities of interest. Sage Research Methods, http://srmo.sagepub.com/view/the-sage-encyclopedia-of-socialscience-research-methods/n768.xml 
5. The Global Non-Response Rate (GNR) has been calculated for all Canadian places for the NHS 2011 in order to rate the quality of data that was gathered. The GNR comprises surveys that were not fully completed and those not returned. In far too many northern communities, this rate can exceed $35 \%$; for Ile a la Crosse it exceeded $50 \%$ and as such the NHS was not released. For the official definition see: http://www12.statcan.gc.ca/nhsenm/2011/as-sa/fogs-spg/Pages/GNR.cfm?lang=E\&level=2\&GeoCode=12

6. The ICNGD purchased data on "contact with nature" from Statistics Canada in order to populate this domain.

7. Statistics Canada, Table 051-0059. Estimates of population by economic region, sex and age group for July 1, based on the Standard Geographical Classification (SGC) 2011, annual (persons)

8. Most percentages in this text have been rounded up or down to closest whole number in order to increase accessibility for generalist readers (except where the percentage is .5).

9. See Statistics Canada, https://www12.statcan.gc.ca/nhs-enm/2016/ref/ questionnaires/questions-eng.cfm

10. This table does not include employment in mineral exploration nor in any oil and gas works active in the region.

11. See Government of Canada, Feb 09, 2012, http://pm.gc.ca/eng/ node/21788 and Mining.Com, April 15, 2015 http://www.mining.com/ canada-india-sign-historic-uranium-supply-deal/

12. We have not generated population projections for the community as these are not sensitive to, nor calibrated for, economic change. Yet economic change will be one of the largest drivers of demographics in the near future as mineral developments occur in the region.

13. Other small places being collectively reported within Census Division 18, Unorganized.

14. The Saskatchewan Health Care file provides yearly population estimates, which provide an alternative means of assessing population; these are discussed in the primary report. Correspondence between authors and with Mr. Curtis Woloschuk, Saskatchewan Bureau of Statistics (Curtis. Woloschuk@gov.sk.ca, Nov. 17, 2014)

15. Due to random rounding we have a total population of $101 \%$.

16. See http://www.med.uottawa.ca/sim/data/Vital_Stats_e.htm

17. We would also expect to see high numbers of children living with grandparents, which was a reported metric in the NHS 2011, but is not available for Île-à-la-Crosse due to low-response-rate suppression.

18. In September 2014, and as part of an ongoing program of improving access to affordable housing in the north The Government of Canada and the Province of Saskatchewan, along with the Northern Village of Île-àla-Crosse and SDC Construction Ltd., started construction of five single 
family homes in Île-à-la-Crosse. While these five home will help relieve some of the pressure on crowding in the community we should note that in 2011 there were 45 single parent mothers with three or more children, so just based on this one proxy measure of low-income and housing needs the investment in five new homes, while much heralded by the government would represent only a $9 \%$ solution for this one group of low income residents. See Government of Canada news release: Groundbreaking for New Affordable Housing in Île-À-La-Crosse, September 14, 2014; http:// www.cmhc-schl.gc.ca/en/corp/nero/nere/2014/2014-09-10-1200.cfm

19. The 2001 labour force population numbers had to be derived using the labour force percentages times the labour force size estimated as the population 20-64 from the 2001 Census, as we could not estimate 15-19 year olds still in school, as the community profiles only provide percentages for each of the three categories above. This means we are probably underestimating 2001 labour force population.

20. Due to random rounding we tally 300, not 305.

21. Human-capital theory: This is a modern extension of Adam $\underline{\text { Smith's }}$ explanation of wage differentials by the so-called net (dis)advantages between different employments. The costs of learning the job are a very important component of net advantage and have led economists such as Gary S. Becker and Jacob Mincer to claim that, other things being equal, personal incomes vary according to the amount of investment in human capital; that is, the education and training undertaken by individuals or groups of workers. A further expectation is that widespread investment in human capital creates in the labour-force the skill-base indispensable for economic growth. http://www.encyclopedia.com/doc/1O88Humancapitaltheory.html, accessed May 24, 2015. The correspondence principle, or correspondence thesis, is a sociological theory that posits a close relationship between social standing and the educational system. Writers in this vein are in particular interested in the relationship between a person's social standing and the type of education that is received at school. In its most basic form the principle states that the social relations of the school can be directly related to those in the work-place, meaning that educational institutions prepare students for their future work roles. Apart from the formal curriculum that is offered by the school, the advocates of the correspondence principle argue that the structure of the school and also the personal experience given to each student (the hidden curriculum) is important to their future socialization. They also emphasize that there is a strong relationship between the child's education and the interaction they have with their parents at home. There is a significant intergenerational replication of consciousness and socialized inequality via the linkages among the authority relations experienced by fathers at work, transferred to childrearing styles, and replicated in school interaction with 
teachers. Source: http://en.wikipedia.org/wiki/Correspondence_principle_ (sociology); May 24, 2015

22. Lower attendance rates could, though, be partially explained by time on the land hunting with family, which speaks positively to both the cultural vitality and contact with nature domains (see below). This is a metric which would require new administrative data gathering.

23. Robert Half, The Specialist Economy, How Business and Professionals can prepare for the trend towards Specialization, Robert Half International, accessed January 27, 2015, https://www.roberthalf.com/sites/default/files/ Media_Root/Images/RH-PDFs/RH_specialist_economy_whitepaper_SEC. pdf

24. Statistics Canada: Skills in Canada: First Results from the Programme for the International Assessment of Adult Competencies (PIAAC) Tourism and the Centre for Education Statistics Division Main Building, Room 2001, Ottawa, K1A 0T6, Catalogue no. 89-555-X ISBN 978-1-100-22678-1

25. Île-à-la-Crosse was once dubbed the saddest and drunkest community in Canada by Fifth Estate and the Leader Post, Eagle Feather News, July 29, 2014, http://www.eaglefeathernews.com/arts/index.php?detail=635

26. Jason Warick, Canwest News Service January 21, 2010; Infant mortality is defined as babies who are born alive but die before their first birthday.

27. However, caution should be taken when comparing these rates between regions or over time as there can be large fluctuations in the three-year averages due to the small populations in the northern regions. Northern Saskatchewan Health Indicators Report 2011.

28. This data order has been placed with Statistics Canada and will result in a future publication.

29. In our community report we add three additional measures of community health assessment; these are life expectancy (74.1 years, which is lower than Canada and Saskatchewan); teenage pregnancy (4.6 times higher than the provincial rate); and self-rated health (10 percentage points lower than the provincial rate at $48.3 \%$ reporting very good to excellent health, compared to $58.1 \%$ provincially).

30. See Statistics Canada, Table 1: Population with an Aboriginal mother tongue by language family, main languages within these families and their main provincial and territorial concentrations, Canada, 2011. http:// www12.statcan.gc.ca/census-recensement/2011/as-sa/98-314-x/2011003/tbl/ tbl3_3-1-eng.cfm

31. See http://216.174.135.221/michif/michiflanguage.html; We also find immigrant families from southeast Asia, numbering twenty in the 2011 Census, who speak four different langauges including Lao, Tamil, and Malayalam, suggestive of a recent influx of immigrants not captured in the 2006 Census. 
32. We have not included a discussion on proportional representation, which is required by this domain, as it is not possible to collect ethnic origins of elected officials without ethics permissions. The ability of an Aboriginal people to elect their own officials should be in proportion to their percentage of the population.

33. It also includes language vitality, which has been reviewed in the cultural domain section.

34. See "Planning for Growth North, Saskatchewan Ministry of Government Relations, "Northern Village of Ile-a-la-Crosse" http://www. planningforgrowthnorthsk.com/icircle-agrave-la-crosse.html, last modified July 2014

35. See Indigenous and Northern Affairs Canada website for definition of Crown ownership on Indian Reserves: https://www.aadnc-aandc.gc.ca/eng 1100100034737/1100100034738; accessed March 26, 2016

36. Statistics Canada, Household Food Insecurity in Canada in 2007-2008: Key Statistics and Graphics

37. Northern Saskatchewan Health Indicators Report 2011. The average weekly cost of the nutritious food basket in the Far North was almost twice as expensive as a large city in the south. This could be the difference of nearly $\$ 715 /$ month

38. It would be advisable to carry out a business survey in the northern communities, which would include questions on labour force demand and the challenges of filling positions.

39. The duty to consult is founded on the honour of the Crown, which requires that the Crown (or an agent of the Crown) consult with and, if required, accommodate the interests of the Aboriginal peoples when the Crown is aware of real or asserted existence of an Aboriginal or treaty right and contemplates a decision that might adversely affect the exercise of that right. See Indigenous and Northern Affairs Canada, https://www. aadnc-aandc.gc.ca/eng/1100100014649/1100100014653 


\section{The Northern Review \\ yukoncollege.yk.ca/review}

\section{Book Review}

From Treaty Peoples to Treaty Nation: A Road Map for All Canadians. By Greg Poelzer and Ken S. Coates. Vancouver, BC: UBC Press, 2015, 337 pp including index. Reviewed by Georgina Martin.

Examining the political and social meaning of neo-liberal ideals in Canada consists of a focus on the market and the free movement of goods, while also considering how governments prefer to reduce spending on services such as education and health care. This book examines neo-liberal ideals and helps Canadians locate common ground within a neo-liberal discourse. Greg Poelzer and Ken Coates present a comprehensive overview of how Indigenous peoples can be considered in the restructuring of the political and economic landscape. From Treaty Peoples to Treaty Nation: A Road Man for All Canadians strongly lays out the debate to restructure Canada. Nonetheless, a central tenet of the discourse is the assumption that restructuring will ease the tensions between Treaty peoples and Canada, as a Treaty Nation, as a whole. I recommend that consideration from Indigenous perspectives will balance the debate.

The political, social, and educational considerations underpinning From Treaty Peoples to Treaty Nation is considering how the "debate over Aboriginal futures, if handled in a respectful and constructive manner, could build national awareness of the building blocks of Confederation and greater understanding of how a divisible Crown can operate" (278-9). In Part One, Aboriginal Leaders and Scholars Point the Way, the first chapter, "The Traditionalists," is comprised of five authors who "emphasize a critique of the status quo, but none ... suggest how Aboriginal autonomy would work in practice" (45). That may be, but I admire the Indigenous scholarly views that are crucial for representing traditional practices drawn from lived experiences. The chapter "Treaty Federalism," focuses on how "[t]reaty federalism represents an important constitutional and administrative option for Canada and could be the centrepiece of future efforts towards political reconciliation. The key to the concept is that Aboriginal peoples would be consenting to join Canada as full and respected partners in national federalism" (52). Much of this discussion offers alternatives and models for Aboriginal peoples to participate in 
the Canadian federal political system by securing Aboriginal rights, yet I see no direct route to satisfy all Aboriginal communities. The chapter "Bridging the Solitudes" concludes the first section with a call to "create mutual understanding and to ensure respectful interaction between cultures in Canada" to find "the means to understand and accommodate Aboriginal people within society" (59). The ideas exposed in this chapter highlight the complex and controversial Aboriginal positions on legal, political, and constitutional entitlements as penned by Poelzer and Coates. As expected, the issues are intense and diverse, especially around the assertion of sovereignty.

Part Two considers Non-Aboriginal Views on the Way Forward in terms of "Legal Rights, Moral Rights, and Well-Being" and "Political and Institutional Approaches." In expressing these views, Poelzer and Coates concur that "there is no single Aboriginal position on the issues at hand" and "there is no single non-Aboriginal perspective or line of argument" either (79). Continuing with "Legal Rights, Moral Rights, and Well-Being," the strong debate separates into two camps-those who oppose special rights and arrangements for Indigenous peoples and those who support varying degrees of unfettered Indigenous autonomy. An addition to the discussion is that the "critique of Aboriginal self-government rests on firm commitment to the cultural survival of Indians" (101). This commitment appreciates the strengths of Aboriginal cultures as a refusal to being usurped by the priorities of the dominant society. The potential horror, according to Poelzer and Coates, would be replacing the non-Indigenous elite with an Indigenous ruling class.

In "Political and Institutional Approaches," it is affirmed that "the answer to current issues lies in the exercise of institutionalized political power" (102). The scholars in this debate emphasize the need to reform political structures and extend Aboriginal governments and organizations the powers they need. I recognize that the positions and ideologies among the scholars are acutely polarized with an agreement that the current situation is not plausible, yet it seems that decisive actions are emerging.

In Part Three, Coming at It from a Different Direction-Aboriginal Success Stories, the first chapter, "Culture and Education," begins by acknowledging the disparities and brings to the forefront the stark reality of Indigenous peoples' erasure of their languages. There is hope-although Aboriginal students are underrepresented in education, the situation is continuously improving. A recent example is a class of anthropology students who uncovered rich history at a heritage site on the Red River in Manitoba. The find contributes to the importance of First Nations during 
that era, especially in agriculture. This changes academic interpretation of the important role of First Nations as farmers.

The second chapter in this section, "Business and Entrepreneurship," conjures the growth of enterprises through Aboriginal entrepreneurship and industry partnerships. There is no shortage of models across the country, which show the growth of Aboriginal wealth both communally and individually. In "Governance and Civic Engagement," Poelzer and Coates recognize social capital as the ingredient to shape the determination of Aboriginal peoples. Robert Putnam describes social capital as, "those features of social organization such as networks, norms, and social trust that facilitate coordination and cooperation for mutual benefit" (155). The valued engagement with the rest of Canada is important. The approaches are key, especially for British Columbia, the most non-treaty province in the country. I see the path opening for repair and renewal.

Part Four focuses on Steps towards Social, Political, and Economic Equality. The first two chapters, "Global Lessons" and "Equality of Status" are straightforward: "Aboriginal people in Canada deserve ... full equality of opportunity with other Canadians" socially, politically, and economically in addition to the "recognition of their cultures, traditions, and Aboriginal treaty rights" (173). I recognize how positive plans could be forged based on international lessons and conventions, but multicultural models must be avoided. Multicultural models downgrade the significance of the "equality of status" of Indigenous peoples. Equality is described as "equal partners in the past, present, and future of Canada" (189) through meaningful participation. The chapter "Citizenship and a Commonwealth of Aboriginal Peoples" proposes to accommodate "fiscal and political realities, Aboriginal aspirations, non-Aboriginal expectations, and legislative and constitutional commitments" (213). The authors aim for all Indigenous groups in Canada to amalgamate under an arrangement of self-rule. Given the differences and diversity, I see this as a major challenge.

The last three chapters in this section, "Aboriginal Self-Government," "Community-Based Economic Well-Being," and "Finding Common Economic Ground" conclude Poelzer's and Coates's articulation of positive advances based on goodwill. Aboriginal self-government is seen to strengthen Canada's democracy, with the intent to sustain equal opportunity and promote Indigenous peoples' drive to achieve selfsufficiency. As we are in a new era of constitutional reform I expect that goodwill will be forged equally. There is a lot of work to be done with 